\title{
2019 APSA Organized Section Awards
}

I $n$ addition to the APSA awards, the following recognitions were announced by _the APSA Organized Sections.

SECTION 01. FEDERALISM \& INTERGOVERNMENTAL RELATIONS

\section{Martha Derthick Book Award}

The Martha Derthick Book Award is conferred for the best book published at least 10 years ago that has made a lasting contribution to the study of federalism and intergovernmental relations.

Award Committee: Carol Weissert, Chair, Florida State University; Paul Manna, College of William \& Mary; Adam Myers, Providence College

Recipient: Jenna Bednar, University of Michigan

Title: The Robust Federation. Cambridge University Press, 2008.

\section{Daniel Elazar Distinguished Federal- ism Scholar Award}

The Daniel Elazar Distinguished Federalism Scholar Award recognizes distinguished scholarly contributions to the study of federalism and intergovernmental relations.

Award Committee: Paul Nolette, Marquette University; Laura Evans, University of Washington; Henry Hale, George Washington University

Recipient: David E. Wilkins, University of Minnesota

\section{Deil S. Wright Best Paper Award}

The Deil S. Wright Best Paper Award is conferred for the best paper in the field of federalism and intergovernmental relations presented at the previous year's annual meeting of the APSA.

Award Committee: Srinivas Parinandi, Chair, University of Colorado; Claudia Avellaneda, Indiana University; Philip Rocco, Marquette University

Recipients: Will Horne, Princeton University; Alex Kerchner, Princeton University Title: "Exploring the Regional Determinants of Redistributive Preferences." Unpublished manuscript, presented at the American Political Science Association Annual Meeting, 2018.

\section{John Kincaid Best Article Award}

The John Kincaid Best Article Award is conferred on the author(s) of the best article published in Publius: The Journal of Federalism in the previous year.

Award Committee: Mona Vakilifathi, Chair, New York University; David Siroky, Arizona State University; Jennifer Wolak, University of Colorado

Recipient: Karlo Basta, Memorial University of Newfoundland

Title: "The State between Minority and Majority Nationalism: Decentralization, Symbolic Recognition, and Secessionist Crises in Spain and Canada." Publius: The Journal of Federalism 48 (1): 51-75.

\section{SECTION 02. LAW AND COURTS}

\section{Best Graduate Student Paper Award}

The Best Graduate Student Paper Award is given annually for the best paper on law and courts written by a graduate student.

Award Committee: Ellen Ann Andersen, Chair, University of Vermont; Kimberley Fletcher, San Diego State University; Leila Kawar, University of Michigan; David Glick, Boston University; Nancy Arrington; Emory University

Recipient: Anna Gunderson, Emory University

Title: "Why Do States Privatize their Prisons?" Unpublished manuscript.

Recipient: Elizabeth Lane, Michigan State University

Title: "Legal Quality and the United States Supreme Court." Unpublished manuscript.

\section{Teaching and Mentoring Award}

The Teaching and Mentoring Award recognizes innovative teaching and instructional methods and materials in law and courts. Examples of innovations that might be recognized by this award include (but are not limited to) outstanding textbooks, websites, classroom exercises, syllabi, or other devices designed to enhance the transmission of knowledge about law and courts to undergraduate or graduate students.

Award Committee: Michelle Deardorff, Chair, The University of Tennessee at Chattanooga; Laura Moyer, University of Louisville; Elspeth Wilson, Franklin \& Marshall College; Alec Ewald, University of Vermont; Courtenay Daum, Colorado State University

Recipient: Virginia Hettinger, University of Connecticut

\section{Lasting Contribution Award}

The Lasting Contribution Award is given annually for a book or journal article, 10 years or older, that has made a lasting impression on the field of law and courts. Award Committee: Lisa Miller, Chair, Rutgers University; Kenneth Kersch, Boston College; Wayne Moore, Virginia Tech; Emily Zackin, Johns Hopkins University; Yüksel Sezgin, Syracuse University

Recipient: Alec Stone Sweet, National University of Singapore

Title: Governing with Judges: Constitutional Politics in Western Europe. Oxford University Press, 2000.

Recipient: Tamir Moustafa, Simon Fraser University

Title: The Struggle for Constitutional Power: Law, Politics, and Economic Development in Egypt. Cambridge University Press, 2007.

\section{Lifetime Achievement Award}

The Lifetime Achievement Award is an award for a lifetime of significant scholarship, teaching and service to the law and courts field.

Award Committee: Susan Burgess, Chair, Ohio University; Tom Keck, Syracuse University; Gordon Silverstein, Yale University; David Klein, Eastern Michigan University; Susan Haire, University of Georgia Recipient: Gary Jacobsohn, University of Texas at Austin

\section{Best Conference Paper Award}

The Law and Courts Best Conference Paper Award (formerly the American Judicature Society Award) is given annually for the best paper on law and courts presented at the previous year's annual meetings of the American, international, or regional political science associations. Single and coauthored papers, written by political scientists, are eligible. Papers may be nominated by any member of the section.

Award Committee: Anthony Chen, Chair, Northwestern University; Jonathan Chausovsky, State University of New York at Fredonia; Manoj Mate, University of California, Irvine; Sanjay Ruparelia, New School for Social Research; Scott Lemieux, University of Washington

Recipient: Allison P. Harris, Pennsylvania State University

Title: "Can Racial Diversity Among Judges Affect Sentencing Outcomes?” Unpublished 
manuscript, presented at the State Politics and Policy Conference.

\section{Best Journal Article Award}

The Best Journal Article Award recognizes the best journal article on law and courts written by a political scientist and published during the previous calendar year. Award Committee: Rich Pacelle, Chair, University of Tennessee; Tao Dumas, The College of New Jersey; Lisa Holmes, University of Vermont; Doug Rice, University of Massachusetts at Amherst; Tony Smith, University of California, Irvine

Recipient: John Kastellec, Princeton University

Title: "Judicial Federalism and Representation." Journal of Law \& Courts 6 (1): 51-92.

\section{Law and Courts Service Award}

The Law and Courts Service Award recognizes service to the section in the literal sense, as in service on committees and in leadership positions, as well as service within the section, as in service to the profession within the field of law and courts in the form of archiving data, promoting infrastructure, representing the profession in the media, etc.

Award Committee: Christine Nemacheck, Chair, The College of William \& Mary; Laura Hatcher, Southeast Missouri State; Justin Crowe, Williams College; Julio Rios Figureroa, CIDE; Jennifer Fredette, Ohio University

Recipient: Julie Novkov, The State University of New York at Albany

\section{Herman Pritchett Award for Best Book in Law and Courts}

The C. Herman Pritchett award is given annually for the best book on law and courts written by a political scientist and published the previous year (2018).

Award Committee: Pamela Brandwein, Chair, University of Michigan; Stuart Chinn, University of Oregon School of Law; Alison Gash, University of Oregon; Matthew Ingram, The State University of New York at Albany; Amanda HollisBrusky, Pomona College

Recipients: Daniel M. Brinks, University of Texas at Austin; Abby Blass, University of Texas at Austin

Title: The DNA of Constitutional Justice in Latin America: Politics, Governance, and Judicial Design. Cambridge University Press, 2018.

Recipients: Frank R. Baumgartner, University of North Carolina at Chapel Hill; Derek
Epp, University of Texas at Austin; Kelsey Shoub, University of South Carolina Title: Suspect Citizens: What 20 Million Traffic Stops Tell Us About Policing and Race. Cambridge University Press, 2018.

\section{SECTION 03. LEGISLATIVE STUDIES}

\section{Richard F. Fenno Prize}

In the tradition of Professor Fenno's work, this prize is designed to honor work that is both theoretically and empirically strong Moreover, this prize is dedicated to encouraging scholars to pursue new and different avenues of research in order to find answers to previously unexplored questions about the nature of politics.

Award Committee: Sarah Binder, Chair, George Washington University and the Brookings Institution; David Parker, University of Montana; Michael Minta, University of Minnesota

Recipient: C. Lawrence Evans, The College of William \& Mary

Title: The Whips: Building Party Coalitions in Congress. University of Michigan Press, 2018.

\section{Carl Albert Dissertation Award}

The Carl Albert Dissertation Award is given annually for the best dissertation in legislative studies. Topics may be national or subnational in focus-on Congress, parliaments, state legislatures, or other representative bodies.

Award Committee: Alison W. Craig, Chair, University of Texas at Austin; Melinda Ritchie, University of California, Riverside; Wendy Schiller, Brown University Recipient: Nara Park, University of Chicago Title: "The Nature of Japanese Governance: Seikai-Tensin (政界転身)'s Political Success in Postwar Japan, 1947-2014." PhD diss., University of Chicago.

\section{Jewell-Loewenberg Award}

The Jewell-Loewenberg Paper Award for the best article in Legislative Studies Quarterly in the previous year.

Award Committee: Sarah Anzia, Co-Chair, University of California, Berkeley; Terry Moe, Co-Chair, Stanford University; Jennifer Garcia, Oberlin College

Recipient: Adam Zelizer, University of Chicago

Title: "How Responsive are Legislators to Policy Information: Evidence from a Field Experiment in a State Legislature." Legislative Studies Quarterly, 43 (4): 595618.

\section{Alan Rosenthal Prize}

In the spirit of Alan Rosenthal's work, this prize is dedicated to encouraging young scholars to study questions that are of importance to legislators and legislative staff and to conduct research that has the potential application to strengthening the practice of representative democracy. Award Committee: Ruth Bloch Rubin, Chair, University of Chicago; Domingo Morel, Rutgers University-Newark; Charles Shipan, University of Michigan

Recipient: Kristin Wylie, James Madison University

Title: Party Institutionalization and Women's Representation in Democratic Brazil. Cambridge University Press, 2018.

\section{CQ Press Award}

The CQ Press Award for the best paper on legislative studies presented at the previous year's APSA Annual Meeting. Award Committee: Olle Folke, Co-Chair, Uppsala University; Johanna Rickne, CoChair, Stockholm University; Emily Schilling, University of Tennessee, Knoxville Recipients: Andreu Casas, New York University; Matthew J. Denny, Facebook Washington DC; John Wilkerson, University of Washington

Title: "More Effective Than We Thought: Accounting for Legislative Hitchhikers Reveals a More Inclusive and Productive Lawmaking Process." Unpublished manuscript, presented at the APSA Annual Meeting, 2018.

\section{Barbara Sinclair Legacy Award}

The Barbara Sinclair Legacy Award is designed to honor the work of a scholar or set of scholars who have contributed a lifetime of significant scholarship to the study of legislative politics. In the tradition of Professor Sinclair's body of work, recipients of this award will have focused on individual legislative behavior, institutional rules, or the role of party in shaping legislative politics. This award is also intended to recognize scholars who employ a range of methods in their research.

Award Committee: Tracy Sulkin, Chair, University of Illinois; John Wilkerson, University of Washington; Nate Monroe, University of California, Merced

Recipients: John Aldrich, Duke University; David W. Rohde, Duke University

\section{Emerging Scholar Award}

The Emerging Scholar award is designed to recognize a scholar who is no more than 
six years from the year of their $\mathrm{PhD}$ who has informed the study of legislative politics through innovative and rigorous scholarship. The recipient of this award will be an individual who has a strong early career publication trajectory and has presented their work actively at conferences and other public venues.

Award Committee: Tiffany Barnes, CoChair, University of Kentucky; Justin Kirkland, Co-Chair, University of Virginia; Christian Grose, University of Southern California

Recipient: Molly Reynolds, Brookings Institution

\section{SECTION 04. PUBLIC POLICY}

\section{Aaron Wildavsky Enduring Contribu- tion Award}

The Aaron Wildavsky Enduring Contribution Award is given for the best book or article published in the general area of public policy during the past 20 to 30 years.

Award Committee: Jeffrey Milyo, University of Missouri; Leah Stokes, University of California, Santa Barbara; Jonathan Mummolo, Princeton University

Recipients: James Mahoney, Northwestern University; Kathleen Thelen, The Massachusetts Institute of Technology

Title: A Theory of Gradual Institutional Change. Explaining Institutional Change: Ambiguity, Agency and Power. Cambridge University Press, 2010.

\section{Best Comparative Policy Paper Award (with JCPA)}

The Best Comparative Policy Paper Award recognizes a paper presented at the APSA Annual Meeting which is of particular distinction in the area of comparative public policy. It is granted in collaboration with and sponsored by the International Comparative Policy Analysis Forum and the Journal of Comparative Policy Analysis.

Award Committee: Jane Gingrich, University of Oxford; Ling Zhu, University of Houston; Tiffany Barnes, University of Kentucky; Jacint Jordana, Universitat Pompeu Fabra; Xufeng Zhu, Tsinghua University Recipient: Agustina Paglayan, University of California, San Diego

Title: "Democracy and Educational Expansion: Evidence from 200 years." Unpublished manuscript.

\section{Best Poster on Public Policy Award}

The Best Poster on Public Policy Award is given for the best paper or poster presented at the poster session at the previous APSA meeting.

Award Committee: Brenda Bushouse, Chair, University of Massachusetts at Amherst; Kenneth Lowande, University of Michigan; Delphia Shanks-Booth, Hendrix College Recipients:Wenhui Feng, The State University of New York at Albany; Erika G. Martin, The State University of New York at Albany

Title: "Variation in Local Health Departments' Involvement in Implementing Obesity Policies." Unpublished manuscript.

\section{Best Paper on Public Policy Award}

The Best Paper on Public Policy Award recognizes the best paper on public policy given at the previous APSA Annual Meeting.

Award Committee: Chris Witko, Pennsylvania State University; Tabitha Bonilla, Northwestern University; Clare Brock, Texas Woman's University

Recipient: Jake Grumbach, University of Washington

Title: "When Governments only Learn From Co-partisans: Partisan Policy Diffusion." Unpublished manuscript.

\section{Theodore J. Lowi Policy Studies Jour-} nal Best Article Award

The Theodore J. Lowi Policy Studies Journal Best Article Award is given to recognize an article of particular distinction published at any time in Policy Studies Journal. Award Committee: Candis Watts Smith, Chair, University of North Carolina at Chapel Hill; Mallory SoRelle, Lafayette College; Amy McKay, University of Exeter Recipients: Anne L. Schneider, Arizona State University; Helen M. Ingram, University of California, Irvine

Title: "Social Constructions, Anticipatory Feedback Strategies, and Deceptive Public Policy." Policy Studies Journal 47 (2): 206236.

\section{Excellence in Mentoring Award}

The Excellence in Mentoring Award has been established to recognize sustained efforts by a senior scholar to encourage and facilitate the careers of emerging political scientists in the field of public policy.

Award Committee: Jamila Michener, Chair, Cornell University; Rachel Augustine Potter, University of Virginia; Derek Epp, University of Texas at Austin

Recipient: Amanda Bittner, Memorial University of Newfoundland
SECTION 05. POLITICAL

\section{ORGANIZATIONS AND PARTIES}

\section{Emerging Scholars Award}

Given to a scholar who has received his or her $\mathrm{PhD}$ within the last five years and whose career to date demonstrates unusual promise.

Award Committee: Stephen Medvic, Chair, Franklin and Marshall College; Kay Lehman Schlozman, Boston College; Ann-Kristin Koelln, Aarhus University

Recipient: Danielle Thomsen, University of California, Irvine

\section{Jack Walker Award}

The Jack Walker Award recognizes an article published in the last two calendar years that makes an outstanding contribution to research and scholarship on political organizations and parties.

Award Committee: Jennifer Victor, Chair, George Mason University; Matt Grossman, Michigan State University; David Hopkins, Boston College

Recipients: Alexander Hertel-Fernandez, Columbia University; Matto Mildenberger, University of California, Santa Barbara; Leah S. Stokes, University of California, Santa Barbara

Title: "Legislative Staff and Representation in Congress." American Political Science Review 113 (1): 1-18.

\section{Leon D. Epstein Outstanding Book Award}

Recognizes a book published in the last two calendar years that made an outstanding contribution to research and scholarship on political organizations and parties.

Award Committee: Michael Franz, Chair, Bowdoin College; Scott Ainsworth, University of Georgia; Bruce Larson, Gettysburg College

Recipient: Devin Caughey, Massachusetts Institute of Technology

Title: The Unsolid South: Mass Politics and National Representation in a One-Party Enclave. Princeton University Press, 2018.

\section{Samuel J. Eldersveld Career Achievement Lifetime Award}

The Samuel J. Eldersveld Career Achievement Lifetime Award recognizes a scholar whose lifetime professional work has made an outstanding contribution to the field. Award Committee:Frank Baumgartner,Chair, University of North Carolina at Chapel Hill; Patrick Bernhagen, University of Stuttgart; Gregory Koger, University of Miami 
Recipients: David Lowery, Pennsylvania State University; Virginia Gray, University of North Carolina at Chapel Hill

\section{POP Party Politics Best 2018 APSA Paper Award}

The POP/Party Politics Award recognizes the best paper delivered on a Political Organizations and Parties-sponsored panel at the 2018 APSA Annual Meeting.

Award Committee:Heath Brown, Chair, The City University of New York John Jay College of Criminal Justice; Marie Hojnacki, Pennsylvania State University; Robin Kolodny, Temple University

Recipient: Matt Lacombe, Northwestern University

Title: "The Political Weaponization of Gun Owners: The NRA's Group Social Identity." Presented at the APSA Annual Meeting, 2018.

\section{POP Party Politics Best 2017 APSA Paper Award}

The POP/Party Politics Award recognizes the best paper delivered on a Political Organizations and Parties-sponsored panel at the 2017 APSA annual meeting.

Award Committee: Thomas Holyoke, California State University, Fresno; Diana Dwyer, California State University, Chico; Jesse Crosson, University of Michigan Recipients: Alexander Furnas, University of Michigan; Michael Heaney, University of Glasgow; Timothy LaPira, James Madison University

Title: "The Partisan Ties of Lobbying Firms." Presented at the American Political Science Association Annual Meeting, 2017.

\section{SECTION 06. PUBLIC} ADMINISTRATION

\section{Herbert Kaufman Award}

The Herbert Kaufman Committee selects the best paper presented on a panel sponsored (or co-sponsored) by the Public Administration section at the APSA Annual Meeting each year.

Award Committee: Amanda Girth, Chair, The Ohio State University; Claudia Avellaneda, Indiana University; Nathan Favero, American University

Recipients: K. Jurée Capers, Georgia State University; Candis W. Smith, University of North Carolina at Chapel Hill

Title: "Crossing Ethnic Lines: Immigrant Representation in Bureaucratic Agencies." Unpublished manuscript.
Herbert A. Simon Best Book Award The Herbert A. Simon Book Award is for significant contributions to public administration scholarship.

Award Committee: Karen Mossberger, Chair, Arizona State University; Jiaqi Liang, University of Illinois at Chicago; Aaron Deslatte, Northern Illinois University

Recipient: William Resh, University of Southern California

Title: Rethinking the Administrative Presidency: Trust, Intellectual Capital, and Appointee-Careerist Relations in the George W. Bush Administration. Johns Hopkins University Press, 2015

\section{Paul A. Volcker Junior Scholar Research Grant Award}

Awarded to junior scholars researching public administration issues that affect governance in the United States and abroad. Proposals will be judged on their potential to shed new light on important public administration questions, their scholarly and methodological rigor and their promise for advancing practice and theory development.

Award Committee: William Resh, Chair, University of Southern California; Alisa Moldavanova, Wayne State University; Cullen Merritt, Indiana University-Purdue University Indianapolis

Recipient: Kate Albrecht, University of Illinois at Chicago

Title: "Risk, reward, and rationality? Toward a theory of partner selection between well-resourced and distressed local governments." Unpublished manuscript.

Recipients: Hongseok Lee, The State University of New York at Albany; Sean Webeck, Defense Resources Management Institute

Title: "Bureaucratic Discretion, Psychology, and the Micro-Foundations of Active Representation." Unpublished manuscript.

\section{SECTION 07. CONFLICT PROCESSES}

\section{Lifetime Achievement Award}

The Lifetime Achievement award is given every other year in recognition of scholarly contributions that have fundamentally improved the study of conflict processes. Award Committee: Govinda Clayton, Chair, ETH-Zurich; Elizabeth Menninga, University of Iowa; Cullen Hendrix, Denver University
Recipient: Brett Ashley Leeds, Rice University

\section{J. David Singer Data Innovation Award}

The J. David Singer Data Innovation Award is given for the best data contribution to the study of any and all forms of political conflict, either within or between nationstates.

Award Committee: Molly Melin, Chair, Loyola University Chicago; Jun Koga Sudduth, University of Strathclyde; Idean Salehyan, University of North Texas

Recipients: Paul Hensel, University of North Texas; Sara Mitchell, University of Iowa Title: Issue Correlates of War (ICOW)

\section{Best Paper Award}

This award is given annually for the best paper written by one or more untenured scholars (graduate students, post-docs, or faculty) and presented as part of a conflict processes sponsored panel or poster session at the previous annual meeting. Award Committee: Emily Ritter, Chair, Vanderbilt University; Matt Fuhrmann, Texas A\&M University; Jessica Stanton, University of Minnesota

Recipients: Sara M. T. Polo, University of Essex; Julian Wucherpfennig, Hertie School of Governance

Title: "Trojan Horse, Copycat, or Scapegoat? Unpacking the Refugees-Terrorism Nexus." Unpublished manuscript, presented at the APSA Annual Meeting, 2018.

\section{SECTION 08. REPRESENTATION AND ELECTORAL SYSTEMS}

\section{George H. Hallet Award}

The George H. Hallett Award is presented annually to the author of a book published at least ten years ago that has made a lasting contribution to the literature on representation and electoral systems.

Award Committee: Pippa Norris, Chair, Harvard University; Rikhil Bhavnani, University of Wisconsin-Madison; Ruth Dassonneville, Université de Montréal

Recipient: Mona Lena Krook, Rutgers University

Title: Quotas for Women: Gender and Candidate Selection Reform Worldwide. Oxford University Press 2009.

\section{Lawrence Longley Award}

The Lawrence Longley Award is given for the best article published in the previous year. 
Award Committee: Zoli Hajnal, Chair, University of California, San Diego; Christina Farhart, Carleton College; Meg Rincker, Purdue University Northwest

Recipients: Nasos Roussias, University of Sheffield; Ruben Ruiz-Rufino, King's College London

Title: “'Tying incumbent's hands': The effects of election monitoring on electoral outcomes." Electoral Studies 54: 116-127.

\section{Leon Weaver Award}

The Leon Weaver Award is given for the best paper presented at the previous year's annual meeting at a panel sponsored by the Representation and Electoral Systems Division.

Award Committee: Jennifer Merolla, Chair, University of California, Riverside; Eric Juenke, Michigan State University; Sherrill Stroschein, University College London Recipient: Karen L. Jusko, Stanford University

Title: "Opportunity, not Grievance: The Strategic Entry of the Norwegian Labor Party." Unpublished manuscript, presented at the APSA Annual Meeting, 2018.

\section{SECTION 09. PRESIDENTS AND} EXECUTIVE POLITICS

\section{Richard E. Neustadt Award for Best Book on Executive Politics}

The Richard E. Neustadt Award for the best book published during the year that contributed to research and scholarship in the field of American presidency.

Award Committee: Michelle Belco, Chair, University of Houston; Ignacio Arana, Carnegie-Mellon University; Craig Goodman, University of Houston-Victoria; Austin Trantham, Jacksonville University Recipients: John Sides, George Washington University; Michael Tesler, University of California, Irvine; Lynn Vavreck, University of California, Los Angeles

Title: Identity Crisis: The 2016 Presidential Campaign and the Battle for the Meaning of America. Princeton University Press, 2018.

\section{The Legacy Award}

The Legacy Award will be given to a living author for a book, essay, or article, published at least 10 years prior to the award year that has made a continuing contribution to the intellectual development of the fields of presidency and executive politics. Award Committee: Lilly Goren, Chair, Carroll University; Neil Chaturvedi, California
State Polytechnic University, Pomona; Matthew Eshbaugh-Soha, University of North Texas; Michael Genovese, Loyola Marymount University

Recipient: Shirley Anne Warshaw, Gettysburg College

Title: Powersharing: White House-Cabinet Relations in the Modern Presidency. SUNY Press, 1996.

\section{Founder's Best Paper Award}

The Founders Award honoring Michael Grossman is given for the best paper on executive politics authored by a PhD-holding scholar at the previous year's APSA Annual Meeting.

Award Committee: Brian Newman, Chair, Pepperdine University; Alexander Bolton, Emory University; Charles Lamb, University of Buffalo; Alissandra T. Stoyan, Kansas State University

Recipients: Julia Azari, Marquette University; William D. Adler, Northeastern Illinois University

Title: "The Party Decides (Who the Vice President Will Be)." Unpublished manuscript, presented at the APSA Annual Meeting, Boston, MA, 2018.

\section{Founder's Best Graduate Student Paper Award}

The Founders Award honoring Fred I. Greenstein is given for the best paper on executive politics presented by a graduate student at either the preceding year's APSA Annual Meeting or at any of the regional meetings in 2017 or 2018.

Award Committee: Randy Adkins, Chair, University of Nebraska Omaha; John Dearborn, Yale University; Alison Howard, Dominican University of California; Shannon Bow O'Brien, University of Texas Recipient: Christina M. Kinane, University of Michigan

Title: "Control Without Confirmation: The Politics of Vacancies in Presidential Appointments or Administration Without Confirmation: The Value of Absent and Interim Appointees." Unpublished manuscript, presented at the APSA Annual Meeting, Boston, MA, 2018.

\section{George C. Edwards, III Dissertation Award}

The George C. Edwards, III Dissertation Award is given for the best dissertation in presidency research completed and accepted during the previous two calendar years (January 1, 2017 - December 31, 2018).
Award Committee: Donna Hoffman, Chair, University of Northern Iowa; Yu Ouyang, Purdue University Northwest; Andrew Reeves, Washington University in St. Louis; Zak Taylor, Georgia Institute of Technology

Recipient: Matthew Zarit, University of Pittsburgh

Title: "Lost in Translation: How Bureaucratic Hierarchies Limit Presidential Control Over Distributive Policymaking in U.S. Federal Agencies." PhD diss., University of Pittsburgh.

\section{SECTION 10. POLITICAL METHODOLOGY}

Society for Political Methodology Poster Award (Student Poster, Methods Category)

Recognizes the best political methodology poster given at any political science conference in the preceding year.

Award Committee: Justin Esarey, Chair, Rice University; Ines Levin, University of California, Irvine; Chris Lucas, Washington University in St. Louis

Recipient: Erin Rossiter, Washington University in St. Louis

Title: "Measuring Visual Messages: Political Violence and Computer Vision."

\section{Society for Political Methodology Poster Award (Student Poster, Applications Cat- egory)}

Recognizes the best political methodology poster given at any political science conference in the preceding year.

Award Committee: Alex Tahk, Chair, University of Wisconsin-Madison; Mark Pickup, Simon Fraser University; Michelle Torres, University of Wisconsin-Madison Recipient: Kelsey Shoub, The University of North Carolina at Chapel Hill

Title: "How Changing Frame Sets Alters Legislative Outcomes in Congress."

\section{Society for Political Methodology Poster Award (Faculty Poster)}

Recognizes the best political methodology poster given at any political science conference in the preceding year.

Award Committee: Curt Signorino, Chair, University of Rochester; Dan Hopkins, University of Pennsylvania; Kim Twist, San Diego State University

Recipient: Erin Hartman, University of California, Los Angeles

Title: "Equivalence Based Falsification Tests for Regression Discontinuity Designs.” 
Latin American Political Methodology Meeting Best Poster Award

Award Committee: John Londregan, Princeton University; Carmen Le Foulon, Universidad Católica de Chile; Santiago Olivella, The University of North Carolina at Chapel Hill; Luis Maldonado, Universidad Católica de Chile; Santiago López-Cariboni, Universidad Católica del Uruguay

Recipient: Sofia B. Vera, University of Pittsburgh

Title: "Electoral Accountability in Highly Unstable Party Systems: Experimental Evidence from Latin America."

\section{Asian Political Methodology Meeting Best Poster Award}

Award Committee: Kentaro Fukumoto, Chair, Gakushuin University; Fang-Yi Chiou, Academia Sinica; Benjamin Goldsmith, Australian National University; Kosuke Imai, Harvard University; Koji Kagotani, Osaka University of Economics; Xun Pang, Tsinghua University; Jong Hee Park, Seoul National University

Recipient: Soichiro Yamauchi, Harvard University

Title: "Bias-Corrected Estimator for Difference-in-Differences Design."

Recipient: Naijia Liu, Princeton University Title: "Honest Inference on Missing Data."

\section{Career Achievement Award}

The Career Achievement Award honors an outstanding career of intellectual accomplishment and service to the profession in the Political Methodology field.

Award Committee: Jonathan Katz, California Institute of Technology; Neal Beck, New York University; Jeff Lewis, University of California, Los Angeles; John Londregan, Princeton University

Recipient: Philip Schrodt, Pennsylvania State University

\section{Excellence in Mentoring Award}

The Society for Political Methodology Excellence in Mentoring Award honors members of the Society for Political methodology who have demonstrated an outstanding commitment to mentoring and advising graduate and/or undergraduate students-particularly those from underrepresented groups.

Award Committee: Jacob Montgomery, Chair, Washington University in St. Louis; Nahomi Ichino, University of Michigan; Chad Hazlett, University of California, Los Angeles

Recipient: Gary King, Harvard University

\section{Warren Miller Prize}

Given for the best article in Political Analysis.

Award Committee: Pablo Babera, London School of Economics; Jennifer Pan, Stanford University; Jeff Gill, American University; Jens Hainmueller, Stanford University Recipients: Luke W. Miratrix, Harvard University; Jasjeet S. Sekhon, University of California, Berkeley; Alexander G. Theodoridis, University of California, Merced; Luis F. Campos, Harvard University Title: "Worth Weighting? How to Think About and Use Weights in Survey Experiments." Political Analysis 26 (3): 275-291.

\section{Statistical Software Award}

Recognizes statistical software that has made a significant contribution to the advancement of political science.

Award Committee: Adam Glynn, Chair, Emory University; Sarah Bouchat, Northwestern University; Dustin Tingley, Harvard University

Recipients: Graeme Blair, University of California, Los Angeles; Jasper Cooper, Princeton University; Alexander Coppock, Yale University; Macartan Humphreys, Columbia University and WZB Berlin; Clara Bicalho, WZB Berlin Social Science Center; Neal Fultz, Comake; Lily Medina, WZB Berlin Social Science Center; Aaron Rudkin, University of California, Los Angeles; Luke Sonnet, University of California, Los Angeles

Title: DeclareDesign

\section{Emerging Scholar Award}

The Emerging Scholar Award honors a young researcher, within ten years of their degree, who is making notable contributions to the field of Political Methodology. Award Committee: Luke Keele, Chair, University of Pennsylvania; Arthur Spirling, New York University; Sunshine Hillygus, Duke University; Jake Bowers, University of Illinois

Recipient: Teppei Yamamoto, Massachusetts Institute of Technology

\section{Harold F. Gosnell Prize}

The Harold Gosnell Prize recognizes the best work of Political Methodology presented at a political science conference in the previous year.

Award Committee: Matthew Blackwell, Chair, Harvard University; Marc Ratkovic, Princeton University; Fredrik Savje, Yale University

Recipient:Naoki Egami, Princeton University
Title: "Identification of Causal Diffusion Effects using Stationary Causal Directed Acyclic Graphs."

\section{John T. Williams Dissertation Prize}

In recognition of the John T. Williams' contribution to graduate training, the John $\mathrm{T}$. Williams Award has been established for the best dissertation proposal in the area of political methodology.

Award Committee: Yiqing Xu, University of California, San Diego; Xun Pang, Tsinghua University; Dean Knox, Princeton University

Recipient: Naijia Liu, Princeton University Title: "Essays on Model Selection and Honest Inference.” PhD diss., Princeton University.

\section{The Political Analysis Outstanding} Reviewer Award

The Political Analysis Outstanding Reviewer Award recognizes individuals who have provided exemplary assistance to Political Analysis during the previous year. Outstanding Reviewers are those who provide excellent, timely and productive feedback for authors who have submitted manuscripts to Political Analysis. Outstanding Reviewers are also those who frequently review for the journal, and who provide the editors with productive advice about the submissions they review.

Award Committee: Jeff Gill, American University

Recipients: Jay Goodliffe, Brigham Young University; Natalie Jackson, Public Religion Research Institute

Janet M. Box-Steffensmeier and John A. Garcia ICPSR Summer Program Scholarship

The John A. Garcia Award is a waiver of Program Scholar fees to attend one or both of the ICPSR Summer Program's four-week sessions. The scholarship will be awarded to a maximum of three under-represented graduate students in $\mathrm{PhD}$ programs Award Committee: Saundra K. Schneider, Chair, Michigan State University; Adrienne Hosek, University of California, Davis; Lee Walker, University of North Texas Box-Steffensmeier Award Recipients: Samantha Fuller, Iowa State University; Hyein Ko, University of Iowa; Shana Scogin, University of Notre Dame

Garcia Award Recipients: Marielena Dias, Florida State University; Robert Vidigal, The State University of New York at Stony Brook. 
Advanced Empirical Research on Politics for Undergraduates Program (AERoPUP) Recipient: Matthew Harpe, Harvard University

Title: "The Role of Social Capital in Lowering Drug-, Alcohol- and Suicide-Related Mortality."

Recipient: Nikki Lin, University of Pennsylvania

Title: "Individual Emotional Responses in Young Americans and Their Political Engagement."

Recipient: Yihang (Genna) Liu, Dartmouth College

Title: "Analyzing Truthful Immigration Policy Preferences."

Recipient: Danielle Niangar, University of Houston

Title: "American Public Opinion on Human Rights and Foreign Policy: An Experimental Evaluation."

Recipient: Akhil Rajan, Yale University

Title: "Does 'Identity Politics' Harm Liberals in Redistricting?: Evidence from Majority-Minority Districts."

Recipient: Sierra Wiese, Indiana University Title: "Measuring the Effect of Independent Redistricting Commissions on Gerrymandering."

Recipient: Alan Yan, University of California, Berkeley

Title: "Gain/Loss Framing and Legislator Preferences."

\section{SECTION 11. RELIGION AND} POLITICS

\section{Hubert Morken Book Award}

The Hubert Morken Award is given for the best publication dealing with religion and politics published during the last two years. Award Committee: Nukhet Sandal, Ohio University; Andrew Lewis, University of Cincinnati; Jeremy Menchik, Boston University

Recipient: Marie-Eve Reny, University of Montreal

Title: Authoritarian Containment: Public Security Bureaus and Protestant House Churches in Urban China. Oxford University Press, 2018.

\section{Aaron Wildavsky Dissertation Award}

The Aaron Wildavsky Dissertation Award recognizes the best dissertation on religion and politics successfully defended within the last two years.

Award Committee: Rebecca A. Glazier, University of Arkansas at Little Rock; Ian M. Hartshorn, University of Nevada, Reno;
Eunsook Jung, University of WisconsinMadison

Recipient: Jason Klocek, University of California, Berkeley

Title: "The Cult of Coercion: Religion and Strategic Culture in British Counterinsurgency." PhD diss., University of California Berkeley

\section{Kenneth D. Wald Best Graduate Student} Paper Award

The Kenneth D. Wald Best Graduate Student Paper Award is given annually to a conference paper studying any aspect of religion and politics presented by a $\mathrm{PhD}$ student in political science.

Award Committee: Daniel Bennet, Chair, John Brown University; Nandini Deo, Lehigh University; Benjamin Kroll, Centre College

Recipient: Consuelo Amat, Center on Philanthropy and Civil Society at Stanford University

Title: "The Hydra Effect: When Repression Creates New Opposition against Authoritarianism." Presented at the American Political Science Association Annual Meeting, 2018.

\section{Ted G. Jelen Best Article Award}

This prize is awarded to the best article published in the section's journal Politics and Religion. The winner of the award is selected by the journal's editors.

Award Committee: Amy Eric Smith, Iowa State University; Elizabeth Oldmixon, University of North Texas; Chris Reardon, University of New Hampshire; Paul Djupe, Denison University

Recipients: Elizabeth Sperber, University of Denver; Erin Hern, Syracuse University Title: "Pentecostal Identity and Citizen Engagement in Sub-Saharan Africa: New Evidence from Zambia." Politics and Religion 11 (4): 830-862.

\section{Weber Best Conference Paper Award}

The Best Paper Award recognizes the best paper dealing with religion and politics presented at the previous year's APSA Annual Meeting.

Award Committee: Andre Audette, Chair, Monmouth College; Amanda Friesen, Indiana University-Purdue University Indianapolis; Kerem Ozan Kalkan, Eastern Kentucky University; Rachel Beatty Riedl, Northwestern University

Recipients: Jonathan Chu, University of Pennsylvania; Carrie Lee, United States Air War College
Title: "Race, Religion, and American Support for Humanitarian Intervention." Presented at the American Political Science Annual Meeting, 2018.

\section{SECTION 13. URBAN AND LOCAL POLITICS}

\section{Dennis Judd Best Book Award}

The Best Book Award recognizes the best book on urban politics published in the previous year.

Award Committee: Michael Craw, Chair, University of Arkansas at Little Rock; Stefanie Chambers, Trinity College; Eric Zeemering, University of Georgia

Recipient: Daniel T. O’Brien, Northeastern University

Title: The Urban Commons: How Data and Technology Can Rebuild Our Communities. Harvard University Press, 2018.

\section{Best Dissertation Award}

The Best Dissertation Award is given annually for the best dissertation on urban politics accepted in the previous year.

Award Committee: Daniel Scheller, Chair, University of Texas at El Paso; Zack Taylor, Western University; Melanie Bowers, Rutgers University - Newark

Recipient: Peter Bucchianeri, Vanderbilt University

Title: "The Organization of Conflict in American Local Government." PhD diss. Harvard University.

Byran Jackson Dissertation Research on Minority Politics Award

The Byran Jackson Award recognizes the outstanding scholarship by a graduate student studying racial and ethnic politics in an urban setting.

Award Committee: Diane Wong, Chair, Cornell University; Twyla Larnell, Loyola University Chicago; Jamila Michener, Cornell University

Recipient: Hajer Al-Faham, University of Pennsylvania

Title: "Contingent Citizenship: Muslims in America." PhD diss., University of Pennsylvania.

\section{Norton Long Career Achievement Award}

The Norton Long Career Achievement Award is presented annually to a scholar who has made distinguished contributions to the study of urban politics over the course of a career through scholarly publication 
the mentoring of students, and public service

Award Committee: Richard Stren, Chair, University of Toronto; Marion Orr, Brown University; Susan Clarke, University of Colorado, Boulder

Recipient: Luis Fraga, University of Notre Dame

\section{The Urban Affairs Review Best Paper} Award

The Urban Affairs Review Best Paper Award is given for the best paper in Urban or Regional Politics presented at the 2018 American Political Science Association conference.

Award Committee: Peter Burns, Chair, Soka University; Kelly LeRoux, University of Illinois at Chicago; Benoy Jacob, University of Nevada, Las Vegas

Recipient: Peter Bucchianeri, Vanderbilt University

Title: "There's More than One Way to Party: Progressive Politics and Representation in Nonpartisan San Francisco.” Unpublished manuscript, presented at the APSA Annual Meeting, 2018.

\section{Susan Clarke Young Scholars' Award}

The Susan Clarke Young Scholars' award recognizes scholars who completed their $\mathrm{PhD}$ within the last three years (or are ABDs).

Award Committee: Laura Reese, Michigan State University

Recipients: Sally A. Nuamah, Duke University; Adam Auerbach, American University

\section{Clarence Stone Scholar Award}

The Clarence Stone Scholar Award recognizes up to two young scholars who are making a significant contribution to the study of urban politics. The award is to be given to up to two post-PhD scholars who are in their career (pre-tenure, or recently advanced within the last three years). Award Committee: Ann Bowman, Chair, Texas A\&M University; Zachary Spicer, University of Toronto; Patricia Kirkland, Princeton University

Recipients: Peter Bucchianeri, Vanderbilt University; Carrie LeVan, Colby College; Sally A. Nuamah, Duke University
SECTION 15. SCIENCE,

TECHNOLOGY, AND

ENVIRONMENTAL POLITICS

\section{Elinor Ostrom Career Achievement Award}

The Career Achievement Award is given to an individual in recognition of their lifetime contribution to the study of science, technology, and environmental politics. Award Committee: Chris Koski, Chair, Reed College; Tom Birkland, North Carolina State University; Sarah Anderson, University of California, Santa Barbara Recipient: Thomas Bernauer, ETH Zurich

\section{Emerging Young Scholar Award}

The Emerging Young Scholar Award is given in recognition of a researcher, within ten years of their $\mathrm{PhD}$ degree, who is making notable contributions to the field of science, technology, and environmental politics.

Award Committee: Aseem Prakash, Chair, University of Washington; Tanya Heikkila, University of Colorado, Denver; Rachel Krause, University of Kansas Recipient: Jonas Meckling, University of California, Berkeley

\section{Lynton Keith Caldwell Award}

The Lynton Keith Caldwell Prize is given for the best book on environmental politics and policy published in the past three years.

Award Committee: Leigh Raymond, Chair, Purdue University; Saba Siddiki, Syracuse University; Roger Karapin, Hunter College, The City University of New York

Recipient: David Vogel, University of California, Berkeley

Title: California Greenin'. Princeton University Press, 2018.

Virginia M. Walsh Dissertation Award The Virginia Walsh Dissertation Award in honor of a young scholar who tragically passed away, is given for the best dissertations in the field of science, technology and environmental politics.

Award Committee: Rob DeLeo, Chair, Bentley University; Megan Ruxton, University of Northern Iowa; Gregory Thaler, University of Georgia

Recipient: Janina Grabs, Yale University

Title: "The Effectiveness of MarketDriven Regulatory Sustainability Governance: Assessing the Design of Private Sustainability Standards and Their Impacts on Latin American Coffee Farmers'
Production Practice." PhD diss., University of Münster.

\section{Don K. Price Award}

The Don K. Price Award recognizes the best book on science, technology, and environmental politics published in the last year. Award Committee: Mark Buntaine, Chair, University of California, Santa Barbara; Anne Clunan, Naval Postgraduate School; Eric Patashnik, Brown University

Recipient: Bentley Allan, Johns Hopkins University

Title: Scientific Cosmology and International Orders. Cambridge University Press, 2018.

\section{The Evan Ringquist Best Paper Award}

The Best Paper Award is given for the best paper published in a relevant journal in the last two years. Relevant journals include political science, public administration, public policy, interdisciplinary environmental science, and science and technology studies journals.

Award Committee: Kirsten Rodine-Hardy, Chair, Northeastern University; Jonas Meckling, University of California, Berkeley; Endre Tvinnereim, University of Bergen

Recipient: Aditya Das Gupta, University of California, Merced

Title: "Technological Change and Political Turnover: The Democratizing Effects of the Green Revolution in India." American Political Science Review 112 (4): 918-938.

\section{Paul A. Sabatier Best Conference Paper Award}

The Paul A. Sabatier Best Conference Paper Award is given for the best paper on science, technology, and environmental politics presented at the previous year's APSA Annual Meeting.

Award Committee: David Shafie, Chair, Chapman University; Gwen Arnold, University of California, Davis; Matt Nowlin, College of Charleston

Recipients: Debra Javeline, University of Notre Dame; Tracy Kijewski-Correa, University of Notre Dame; Angela Chesler, University of Notre Dame

Title: "Does It Matter if You "Believe" in Climate Change? The Example of Coastal Home Vulnerability." Unpublished manuscript, presented at the APSA Annual Meeting, 2018.

The STEP APSA Inclusion Travel Award The STEP APSA Inclusion Travel Award will be granted to graduate students from 
under-represented groups in the discipline who are accepted to present a paper at the annual APSA meeting.

Award Committee: Dorothy Daly, Chair, University of Kansas; Erica Simmons, University of Wisconsin; Iza Ding, University of Pittsburgh

Recipients: Juhi Huda, University of Colorado, Boulder; Jongeun You, University of Colorado, Denver

\section{SECTION 16. WOMEN AND POLITICS RESEARCH}

\section{Best Dissertation Award}

Given for the best dissertation on women and politics completed and accepted in the previous year.

Award Committee: Dawn Teele, University of Pennsylvania; Sonali Chakravarti, Wesleyan University; Katharine Wright, Newcastle University

Recipient: Hind Ahmed Zaki, University of Washington

Title: "In the Shadow of the State: Gender Contestation and Legal Mobilization in the Context of the Arab Spring in Egypt and Tunisia." PhD diss., University of Washington.

\section{Best Paper Award}

Given for the best paper presented at the previous year's annual meeting in the field of women and politics.

Award Committee: Erica Townsend-Bell, Oklahoma State University; Alba Alonso Alvarez, University of Santiago de Compostela; Michaele Ferguson, University of Colorado

Recipient: Nicholas J. G. Winter, University of Virginia

Title: "Ambivalent Sexism and Election 2016." Unpublished manuscript, presented at the APSA Annual Meeting, 2018.

\section{Okin-Young Award in Feminist Political Theory}

The Okin-Young Award is co-sponsored by Women and Politics, Foundations of Political Theory, and the Women's Caucus for Political Science. This award commemorates the scholarly, mentoring, and professional contributions of Susan Moller Okin and Iris Marion Young to the development of the field of feminist political theory. This annual award recognizes the best paper on feminist political theory published in an English language academic journal during the previous calendar year.
Award Committee: Ainsley LeSure, Occidental College; Molly Scudder, Purdue University; Jemina Repo, Newcastle University Recipient: Heath Fogg Davis, Temple University

Title: "Why the 'Transgender' Bathroom Controversy Should Make Us Rethink Sex-Segregated Public Bathrooms." Politics, Groups, and Identities 6 (2): 199-216. Honorable Mention: Ashleigh Campi, Loyola Marymount University

Title: "The Unstable Alliance for School Choice: Social Movements and American Neoliberalism." Polity 50 (3): 398-427.

\section{SECTION 17. FOUNDATIONS OF POLITICAL THEORY}

\section{First Book Award}

The First Book Award is given for a first book by a scholar in the early stages of his or her career in the area of political theory or political philosophy.

Award Committee: Margaret Kohn, University of Toronto; Lisa Ellis, University of Otago; Antonio Vazquez-Arroyo, Rutgers University

Recipient: Yves Winter, McGill University Title: Machiavelli and the Orders of Violence. Cambridge University Press, 2018.

\section{David Easton Award}

The David Easton Award is given for a book that broadens the horizons of contemporary political science by engaging issues of philosophical significance in political life through any of a variety of approaches in the social sciences and humanities.

Award Committee: Kevin Olsen, Chair, University of California, Irvine; Patchen Markell, Cornell University; Lawrie Balfour, University of Virginia

Recipient: Jill Frank, Cornell University Title: Poetic Justice: Rereading Plato's Republic. University of Chicago Press, 2018.

\section{Okin-Young Award in Feminist Political Theory}

The Okin-Young Award is co-sponsored by Women and Politics, Foundations of Political Theory, and the Women's Caucus for Political Science. This award commemorates the scholarly, mentoring, and professional contributions of Susan Moller Okin and Iris Marion Young to the development of the field of feminist political theory. This annual award recognizes the best paper on feminist political theory published in an English language academic journal during the previous calendar year.
Award Committee: Ainsley LeSure, Occidental College; Molly Scudder, Purdue University; Jemina Repo, Newcastle University Recipient: Heath Fogg Davis, Temple University

Title: "Why the 'Transgender' Bathroom Controversy Should Make Us Rethink Sex-Segregated Public Bathrooms.” Politics, Groups, and Identities 6 (2): 199-216.

Honorable Mention: Ashleigh Campi, Loyola Marymount University

Title: "The Unstable Alliance for School Choice: Social Movements and American Neoliberalism." Polity 50 (3): 398-427.

\section{Best Paper Award}

Best Paper Award is given for the best paper presented on a Foundations panel at the previous year's APSA Annual Meeting. Award Committee: Sharon Stanley, University of Memphis; Andrew Dilts, Loyola Marymount University; Torrey Shanks, University of Toronto

Recipient: Cigdem Cidam, Union College Title: "Rousseau's Disastrous Utopias? On the Interchangeability of Political Theory, Pedagogy and Art." Unpublished manuscript, presented at the APSA Annual Meeting, 2018.

\section{SECTION 18. INFORMATION TECH- NOLOGY AND POLITICS}

\section{Best Book Award}

The Best Book Award recognizes the best book in the area of Information Technology and Politics. The contest is limited to books published in the previous calendar year.

Award Committee: Patricia Rossini, University of Liverpool; Joel Penney, Montclair State University; Jeff Gulati, Bentley University

Recipient: Margaret Roberts, University of California, San Diego

Title: Censored: Distraction and Diversion Inside China's Great Firewall. Princeton University Press, 2018.

\section{Best Information Technology \& Politics Article Award}

The Best Published Article Award recognizes the best scholarly article published about Information Technology and Politics. The contest is limited to articles published in the calendar year.

Award Committee: Homero Gil de Zúñiga, University of Vienna; Brian Weeks, University of Michigan; Alberto Ardèvol-Abreu, University of Vienna 
Recipients: Stephen Meserve, Texas Tech University; Daniel Pemstein, North Dakota State University

Title: "Google Politics: The Political Determinants of Internet Censorship in Democracies." Political Science Research \& Methods $6(2): 245^{-263}$

\section{Best Conference Paper Award}

The Best Conference Paper Award recognizes the best conference paper in the area of information technology and politics. Award Committee: Shelley Boulianne, MacEwan University; Jennifer Oser, BenGurion University; Cornelius Puschmann, Leibniz Institute for Media Research Recipients: Cristian Vaccari, Loughborough University; August Valeriani, University of Bologna

Title: "Digital Political Talk and Participation in Established and Third Wave Democracies." Unpublished manuscript, presented at the APSA Annual Meeting, 2018.

\section{Best Dissertation Award}

The Best Dissertation Award recognizes the best dissertation in the area of Information Technology and Politics defended April 1 or later of the previous calendaryear (i.e., after April 1, 2018 for the 2019 award). Award Committee: Juan S. Larrosa-Fuentes, ITESO University; Katherine Haenschen, Virginia Tech University; Sílvia MajóVázquez, Reuters Institute for the Study of Journalism

Recipient: Lizhi Liu, Georgetown University

Title: "From Click to Boom: The Political Economy of E-Commerce in China." PhD diss., Stanford University.

\section{Best Student Paper}

Best student paper presented in information technology and politics at the previous year's APSA meeting.

Award Committee: Catie Bailard, George Washington University; Eric Vorst, Lindenwood University; Emily Thorson, Syracuse University

Recipient: Emily Van Duyn, The University of Texas at Austin

Title: "Hidden Democracy." Unpublished manuscript, presented at the APSA Annual Meeting, 2018.

\section{Best Public-Facing Scholarship}

Best public-facing scholarship published in the previous calendar year (i.e., 2017 for 2018's award call). This includes blog posts and popular press publications intended for a broad public audience.

Award Committee: Daniel Kreiss, University of North Carolina at Chapel Hill; Galen Stocking, Pew Research Institute; Dave Karpf, George Washington University Recipient:Julia Azari, Marquette University

\section{SECTION 19. INTERNATIONAL SECURITY}

\section{Kenneth N. Waltz Dissertation Award}

The Kenneth N. Waltz Dissertation Award is awarded to a successfully defended doctoral dissertation on any aspect of security studies, which has been submitted in final, library copy in previous calendar year. The committee welcomes nominations for dissertations employing any approach (historical, quantitative, theoretical, policy analysis, etc.) to any topic in the field of security studies. Manuscripts are judged according to (1) originality in substance and approach; (2) significance for scholarly or policy debate; (3) rigor in approach and analysis; and (4) power of expression. Award Committee: Joshua Shifrinson, Chair, Boston University; Rose Kelanic, University of Notre Dame; Seva Gunitsky, University of Toronto

Recipient: Jennifer Spindel, University of Minnesota

Title: "Beyond Military Power: The Symbolic Politics Of Conventional Weapons Transfers." PhD diss., University of Minnesota.

Honorable Mention: Ketian Zhang, Massachusetts Institute of Technology

Title: "Calculating Bully: Explaining Chinese Coercion." PhD diss., Massachusetts Institute of Technology.

\section{Best Book from a Non-Tenured Faculty Member Award}

Awarded to the non-tenured faculty member who published the best book in Security Studies.

Award Committee: Sumit Ganguly, University of Indiana; Sean Lynn Jones, Harvard University; Stephen Grenier, The Citadel

Recipient: Robin Marwica, European University Institute

Title: Emotional Choices. Oxford University Press, 2018.

Honorable Mention: Lindsay O'Rourke, Boston College

Title: Covert Regime Change. Cornell University Press, 2018.

\section{Best Article Award}

The International Security organized section of APSA (formerly ISAC) Best Article Award seeks to recognize the best peerreviewed articles in the field of international security and security studies broadly defined each year. Eligible articles must have appeared in print in a relevant peerreviewed journal in 2018. Authors must be IS/ISAC members.

Award Committee: Lindsay P. Cohn, US Naval War College; Ryan Grauer, University of Pittsburgh; Sheena Chestnut Greitens, University of Missouri; Kyle Haynes, Purdue University; Jacqueline Hazelton, US Naval War College; Jason Lyall, Dartmouth College

Recipient: Michael Beckley, Tufts University Title: "The Power of Nations: Measuring What Matters." International Security 43 (2): 7-44.

Honorable Mentions: Allison Carnegie, Columbia University; Austin Carson, University of Chicago

Title: "The Spotlight's Harsh Glare: Rethinking Publicity and International Order." International Organization 72 (3): 627-657.

\section{SECTION 20. COMPARATIVE \\ POLITICS}

\section{Sage Paper Award}

The Sage Best Paper Award is given to the best paper in the field of comparative politics presented at the previous year's APSA Annual Meeting.

Award Committee: Rafaela Dancygier, Chair, Princeton University; Tim Longman, Boston University; Daniel Treisman, University of California, Los Angeles Recipients: Jonathan Homola, Rice University; Miguel Pereira, Washington University in St. Louis; William Simoneau, Independent scholar; Margit Tavits, Washington University in St. Louis

Title: "Legacies of the Third Reich: Concentration Camps and Outgroup Intolerance.' Unpublished manuscript, presented at the APSA Annual Meeting, 2018.

\section{Luebbert Book Award}

The Luebbert Book Award is given for the best book in the field of comparative politics published in the previous two years.

Award Committee: Thad Dunning, Chair, University of California, Berkeley; Anna Grzymala-Busse, Stanford University; Diana Fu, University of Toronto

Recipient: Rafaela Dancygier, Princeton University 
Title: Dilemmas of Inclusion: Muslims in European Politics. Princeton University Press, 2017.

Honorable Mention: Lisa Blaydes, Stanford University

Title: State of Repression: Iraq under Saddam Hussein. Princeton University Press, 2018.

\section{Luebbert Article Award}

The Luebbert Article Award is given for the best article in the field of comparative politics published in the previous two years.

Award Committee: Noam Lupu, Chair, Vanderbilt University; Dominika Koter, Colgate University; Kaija Schilde, Boston University

Recipient: Gabrielle Kruks-Wisner, University of Virgina

Title: "The pursuit of social welfare: Citizen claim-making in rural India." World Politics 70 (1): 122-163.

\section{Lijphart/Przeworski/Verba Data Set Award}

The Data Set Award recognizes a publicly available data set that has made an important contribution to the field of comparative politics.

Award Committee: Elizabeth Zechmeister, Chair, Vanderbilt University; Mihaly Fazekas, University of Cambridge; Arthur Spirling, New York University

Recipients: Bryan D. Jones, The University of Texas at Austin

Title: The Comparative Agendas Project (CAP)

Honorable Mentions: Nils B. Weidmann, Universität Konstanz; Espen Geelmuyden Rød, Uppsala Universitet

Title: The Mass Mobilization in Autocracies Database (MMAD)

\section{SECTION 21. EUROPEAN POLITICS} AND SOCIETY

\section{Best Article Award}

This award is given for the best article dealing with European Politics \& Society published in the last year.

Award Committee: Muiris MacCarthaigh, Chair, Queen's University Belfast; Paolo Graziano, University of Padova; Sabine Saurugger, The Grenoble Institute of Political Studies

Recipients: Melissa Carlson, University of California, Berkeley; Laura Jakli, University of California, Berkeley; Katerina Linos, University of California, Berkeley

Title: "Rumors and Refugees: How Government-Created Information Vacuums
Undermine Effective Crisis Management." International Studies Quarterly 62(3): 671685

Honorable Mentions: Paul Castañeda Dower, University of Wisconsin-Madison; Evgeny Finkel, Johns Hopkins University; Scott Gehlbach, University of Chicago; Steven Nafziger, Williams College

Title: "Collective Action and Representation in Autocracies: Evidence from Russia's Great Reforms." American Political Science Review 112 (1): 125-147.

\section{Best Book Award}

The Best Book Award is given for the best book on European Politics and society published in the previous year.

Award Committee: Christopher Bickerton, Chair, University of Cambridge; Tim Haughton, University of Birmingham; Aida Hozic, University of Florida

Recipient: Jennifer Fitzgerald, University of Colorado Boulder

Title: Close to Home: Local Ties and Voting Radical Right in Europe. Cambridge University Press, 2018.

Honorable Mention: Zsofia Barta, The State University of New York at Albany

Title: In the Red: The Politics of Public Debt Accumulation in Developed Countries. Ann Arbor: University of Michigan Press, 2018.

\section{Ernst B. Haas Best Dissertation Award}

The Ernst B. Haas Best Dissertation Award is given for the best dissertation on European Politics and Society filed during the previous year.

Award Committee: Mark Vail, Chair, Tulane University; Filippo Tronconi, University of Bologna; Sara Watson, Ohio State University

Recipient: Andreas Wiedemann, Princeton University

Title: "Indebted Societies: Modern Labor Markets, Social Policy, and Everyday Borrowing." PhD diss., Massachusetts Institute of Technology.

Honorable Mention: Martijn Mos, University of Leiden

Title: "Normative Ties That Bind? Contesting National and Sexual Minority Rights in a Post-Enlargement Europe." PhD diss., Cornell University.

Honorable Mention: Elsa Massoc, Goethe University Frankfurt

Title: "Banking on States? The Divergent Trajectories of European Finance after the Crisis.” PhD diss., University of California, Berkeley.

\section{Best Paper Award}

The Best Paper Award is given for the best paper given on EPS sponsored panels at the previous annual meetings.

Award Committee: Sophie Meunier, Chair, Princeton University; Liesbet Hooghe, University of North Carolina; Christina J. Schneider, University of California, San Diego

Recipient: Jane Gingrich, University of Oxford; Julia Lynch, University of Pennsylvania

Title: "Integrative Institutions and Mainstream Party Collapse: The Regional Context." Unpublished manuscript, presented at the APSA Annual Meeting, 2018.

\section{Peter Mair Memorial Award}

The Peter Mair Memorial Award will fund the travel of two young scholars to attend the APSA meeting. Named in memory of Professor Peter Mair, one of the foremost scholars of European politics, the award is meant explicitly to enable young scholars of European politics without adequate funding to present a paper in one of the panels organized by the EPS section.

Award Committee: Mark A. Pollack, Chair, Temple University; Carol A. Mershon, University of Virginia; Miguel Otero Iglesias, Elcano Royal Institute

Recipient: Adrián del Río, European University Institute

Title: "Office Insecurity and Elite Defections in Electoral Autocracies." Unpublished manuscript, presented at the APSA Annual Meeting, 2019.

Recipient: Yvonni Markaki, University of Oxford

Title: "Fiscal Impacts of Immigration in the EU: Does Reality Shape Perception?" Unpublished manuscript, presented at the APSA Annual Meeting, 2019.

\section{SECTION 22. STATE POLITICS AND POLICY}

\section{Career Achievement Award}

The Career Achievement Award given every biennium to a political scientist who has made a significant lifetime contribution to the study of politics and public policies in the American states.

Award Committee: Peverill Squire, Chair, University of Missouri; Martha E. Kropf, University of North Carolina at Charlotte; David L. Leal, The University of Texas at Austin

Recipient: William D. Berry, Florida State University 
Christopher Z. Mooney Dissertation Award

This award is given for the best dissertation in American state politics and policy completed during the previous calendar year.

Award Committee: Tracy Osborn, Chair, University of Iowa; Robert Lowry, The University of Texas at Dallas; Antoine Yoshinaka, The State University of New York at Buffalo

Recipient: Tessa Provins, University of California, Merced

Title: "The Value of Legislative Design: A Comparative Analysis of State Legislative Institutions." PhD diss., University of California, Merced.

\section{Best Journal Article Award}

The award recognizes the best journal article on U.S. state politics or policy published during the previous calendar year in any peer-reviewed journal.

Award Committee: Christopher J. Clark, Chair, University of North Carolina at Chapel Hill; Rebecca Gill, University of Nevada, Las Vegas; Daniel Mallinson, Penn State Harrisburg

Recipients: Mirya R. Holman, Tulane University; Anna Mahoney, Tulane University

Title: "Stop, Collaborate, and Listen: Women's Collaboration in US State Legislatures." Legislative Studies Quarterly 43 (2): 179-206.

\section{Virginia Gray Best Book Award}

To be awarded annually to the best political science book published on the subject of U.S. state politics or policy in the preceding three calendar years. Thus, books would be eligible to be considered for the award for three years.

Award Committee: Chris Witko, Chair, Pennsylvania State University; Laurel Harbridge-Yong, Northwestern University; Robynn Kuhlmann, University of Central Missouri

Recipient: Jamila Michener, Cornell University

Title: Fragmented Democracy. Cambridge University Press, 2018.

\section{SPPQ Best Paper Award}

The State Politics and Policy Award is given for the best paper on state politics and policy presented at any professional meeting in the previous calendar year.

Award Committee: Renee Van Vechten, Chair, University of Redlands; Adam
Brown, Brigham Young University; Michael G. Miller, Barnard College

Recipient: Mary Kroeger, University of Rochester

Title: "Bureaucrats as Lobbyists." Presented at the APSA Annual Meeting, 2018.

\section{Tom Carsey Scholars}

Award Committee: Jennifer Wolak, Chair, University of Colorado Boulder; Rebecca Kreitzer, University of North Carolina at Chapel Hill; Jason Windett, University of North Carolina at Charlotte

Recipients: Amanda Sahar d'Urso, Northwestern University; Megan Goldberg, Massachusetts Institute of Technology; Courtney Juelich, University of Iowa; Megan Kennedy, Pennsylvania State University; Zoe Nemerever, University of California, San Diego; Lisa Pringle, Claremont Graduate University; Stefany Ramos, University of North Carolina at Chapel Hill; James Szewczyk, Emory University; Elizabeth Wiener, Emory University; Emma Ricknell, Linnaeus University

\section{SECTION 23. POLITICAI COMMUNICATION}

\section{Doris Graber Outstanding Book Award}

The Doris Graber Outstanding Book Award is given to the most outstanding book in the field of political communication that was published in the past decade.

Award Committee: Rune Slothuus, Aarhus University; Jamie Settle, The College of William \& Mary; Emily Sydnor, Southwestern University

Recipient: Matthew Hindman, George Washington University

Title: The Myth of Digital Democracy. Princeton University Press, 2009.

\section{Timothy E. Cook Best Graduate Student Paper Award}

The Cook Award recognizes the best paper on Political Communication presented by a graduate student at the previous year's APSA Annual Meeting.

Award Committee: Danielle Vinson, Furman University; Brian Weeks, University of Michigan; Kathleen Searles, Louisiana State University

Recipient: Taylor N. Carlson, University of California, San Diego

Title: "Through the Grapevine: Informational Consequences of Interpersonal
Communication." Unpublished manuscript, presented at the APSA Annual Meeting, 2018.

\section{Paul Lazarsfeld Best Paper Award}

The Paul Lazarsfeld Award recognizes the best paper on political communication presented at the previous year's APSA Annual Meeting.

Award Committee: Jennifer Pan, Stanford University; Benjamin Toff, University of Minnesota; Jason Turcotte, California State Polytechnic University, Pomona Recipients: Christopher Bail, Duke University; Lisa Argyle, Princeton University; Taylor Brown, Duke University; John Bumpus, Duke University; Haohan Chen, Duke University; M.B. Fallin Hunzaker, New York University; Jaemin Lee, Duke University; Marcus Mann, Duke University; Friedolin Merhout, Duke University; Alexander Volfovsky, Duke University Title: "Exposure to Opposing Views Can Increase Political Polarization: Evidence from a Large-Scale Field Experiment on Social Media." Unpublished manuscript, presented at the APSA Annual Meeting 2018.

\section{Thomas E. Patterson Best Dissertation Award}

One outstanding doctoral dissertation award in political communication may be given annually. To be considered for the award, the dissertation research must pertain to some aspect of political communication.

Award Committee: Nick Anstead, London School of Economics; Jenifer WhittenWoodring, University of Massachusetts Lowell; Georgia Kernell, University of California, Los Angeles

Recipient: Fabian Guy Neuner, University of Michigan

Title: "Elite Framing and the Legitimacy of Global Governance.” PhD diss., University of Michigan.

\section{Murray Edelman Lifetime Distinguished Career Award}

The Murray Edelman Distinguished Career Award recognizes a lifetime contribution to the study of Political Communication.

Award Committee: Rasmus Kleis Nielsen; Markus Prior, Princeton University; Holli Semetko, Emory University

Recipients: Ann Crigler, University of Southern California; Paolo Mancini, Università di Perugia 
Walter Lippmann Best Published Article Award

This award recognizes the best article published in the field of political communication in the previous calendar year.

Award Committee: Shelley Boulianne, MacEwan University; John Ryan, The State University of New York at Stony Brook; Nathan Kalmoe, Louisiana State University; Mona Kleinberg, University of Massachusetts Lowell

Recipients: Johanna Dunaway, Texas A\&M University; Kathleen Searles, Louisiana State University; Mingxiao Sui, Ferrum College; Newly Paul, Appalachian State University

Title: "News Attention in a Mobile Era." Journal of Computer-Mediated Communication 23 (2): 107-124.

Honorable Mentions: Nicholas A. Valentino, University of Michigan; Fabian G. Neuner, University of Michigan; L. Matthhew Vandenbroek

Title: "The Changing Norms of Racial Political Rhetoric and the End of Racial Priming." The Journal of Politics 8o(3): 757771.

SECTION 24. POLITICS AND HISTORY

\section{J. David Greenstone Book Award}

The J. David Greenstone Book Award recognizes the best book in history and politics in the past two calendar years.

Award Committee: Paul J. Frymer, Chair, Princeton University; Eleonora Pasotti, University of California, Santa Cruz; Jeffrey Selinger, Bowdoin College

Recipient: David Alexander Bateman, Cornell University

Title: Disenfranchising Democracy: Constructing the Electorate in the United States, the United Kingdom and France. Cambridge University Press, 2018.

Recipient: Jessica Trounstine, University of California, Merced

Title: Segregation by Design: Local Politics and Inequality in American Cities. Cambridge University Press, 2018.

Honorable Mention: Thomas Ogorzalek, Northwestern University

Title: Cities on the Hill: Urban Institutions in National Politics. Oxford University Press, 2018.

Mary Parker Follett Prize for Best Article The Mary Parker Follett Prize recognizes the best article on politics and history published in the previous year.

Award Committee:Jason Wittenberg, Chair, University of California, Berkeley; Jenni- fer M. Dixon, Villanova University; Nicole Mellow, Williams College

Recipient: Peter Swenson, Yale University

Title: "Misrepresented Interests: Business, Medicare and the Making of the American Health Care State." Studies in American Political Development 32 (1): 1-23.

Honorable Mention: Shivaji Mukherjee, University of Toronto

Title: "Colonial Origins of Maoist Insurgency in India: Historical Institutions and Civil War." Journal of Conflict Resolution 62 (10): 2232-2274.

\section{Walter Dean Burnham Dissertation Award}

The Walter Dean Burnham Award is given for the best dissertation in the field of politics and history.

Award Committee: Margaret Weir, Chair, Brown University; Jason Brownlee, The University of Texas at Austin; Hillel Soifer, Temple University

Recipient: Matthias Dilling, Oxford University

Title: "Organizational Choices and Organizational Adaptability in Political Parties: The Case of Western European Christian Democracy." $\mathrm{PhD}$ diss., University of Oxford.

Honorable Mention: Adam Lebovitz, Cambridge University

Title: "Colossus: Constitutional Theory in America and France, 1776-1799." PhD diss., Harvard University.

\section{SECTION 25. POLITICAL ECONOMY}

\section{Michael Wallerstein Award}

The Michael Wallerstein Award is given for the best published article in political economy in the previous calendar year.

Award Committee: Rebecca Weitz Shapiro, Chair, Brown University; In Song Kim, Massachusetts Institute of Technology; Edward Malesky, Duke University

Recipients: Paul Castaneda Dower, University of Wisconsin-Madison; Evgeny Finkel, George Washington University; Scott Gehlbach, University of Wisconsin-Madison; Steven Nafziger, Williams College Title: "Collective Action and Representation in Autocracies: Evidence from Russia's Great Reforms." American Political Science Review 112 (1): 125-147.

\section{William H. Riker Book Award}

The Best Book Award, named for William $\mathrm{H}$. Riker, is given for the best book on political economy published during the past three calendar years.
Award Committee: Milan Svolik, Chair, Yale University; Sonal Pandya, University of Virginia; Brian K. Min, University of Michigan

Recipient: Avidit Acharya, Stanford University; Matthew Blackwell, Harvard University; Maya Sen, Harvard University

Title: Deep Roots: How Slavery Still Shapes Southern Politics. Princeton University Press, 2018.

\section{Mancur Olson Best Dissertation Award}

The Best Dissertation Award, named for Mancur Olson, is given for the best dissertation in political economy completed in the previous two years.

Award Committee: Bonnie Meguid, Chair, University of Rochester; Leonardo Arriola, University of California, Berkeley; Pavithra Suryanarayan, Johns Hopkins University Recipient: Victoria Paniagua, Duke University

Title: "Protecting Capital: Economic Elites, Asset Portfolio Diversification, and the Politics of Distribution." PhD diss., Duke University.

Honorable Mention: Nikhar Gaikwad, Yale University

Title: "Identity Politics and Economic Policy." PhD diss., Columbia University.

\section{Fiona McGillivray Best Paper Award}

The Fiona McGillivray Award is given for the best paper in political economy presented at the previous year's APSA Annual Meeting. Award Committee: Rikhil Bhavnani, Chair, University of Wisconsin-Madison; Horacio Alejandro Larreguy Arbesú,

Harvard University; Melissa M. Lee, Princeton University

Recipient: Giuliana Pardelli, Princeton University

Title: "For Profit, Power and Protection: Landed Elites' Incentives to Expand Fiscal Capacity." Unpublished manuscript, presented at the APSA Annual Meeting, 2018.

\section{SECTION 27. NEW POLTICAI SCIENCE}

\section{Christian Bay Best Paper Award}

The Christian Bay Award recognizes the best paper presented on a New Political Science panel at the previous year's annual meeting. Award Committee: Alison Gash, Co-chair, University of Oregon; Priscilla Yamin, Cochair,University of Oregon; Matthew Evans, Northwest Arkansas Community College; Lucrecia Garcia Iommi, Fairfield University 
Recipient: Mark Major, Pennsylvania State University

Title: "Why the South Prevailed: Civil Rights, Anticommunism, and the Origins of the Liberal Media." Unpublished manuscript, presented at the APSA Annual Meeting, 2018.

\section{Michael Harrington Book Award}

The Michael Harrington Book Award recognizes an outstanding book that demonstrates how scholarship can be used in the struggle for a better world.

Award Committee: Gordon Lafer, Chair, University of Oregon; Pamela Stricker, California State University San Marcos; Timothy W. Luke, Virginia Tech; Wendy Wright, Bridgewater State University

Recipient: Keisha Lindsay, University of Wisconsin-Madison

Title: In a Classroom of Their Own: The Intersection of Race and Feminism in All-Black Male Schools. University of Illinois Press, 2018.

\section{Richard Cloward and Frances Fox Piven Award}

The Richard Cloward and Frances Fox Piven Award recognizes an activist group, in the region of the annual meeting that puts the ideals of the New Political Science Section, "to make the study of politics relevant to the struggle for a better world," into practice.

Award Committee: Margaret Groarke, Chair, Manhattan College; Sean Parson, Northern Arizona University; Edwin Dan Jacob, Arkansas State University; Frances Fox Piven (honorary), CUNY Graduate Center Recipient: Black Lives Matter DC

\section{Charles A. McCoy Career Achievement Award}

The Charles A. McCoy Career Achievement Award recognizes a progressive political scientist who has had a long, successful career as a writer, teacher, and activist. Award Committee: Cynthia Enloe, Chair, Clark University; Bradley MacDonald, Colorado State University; Manal Jamal, James Madison University

Recipient: Joseph Schwartz, Temple University

\section{New Political Science Dissertation Award}

For an outstanding political science dissertation finished within the previous year of the APSA meeting which exemplifies the commitment to use scholarship in the struggle for a better world.
Award Committee: Rafael Khachaturian, Chair, University of Pennsylvania; Laura Katz Olson, Lehigh University; Peter Wagner, University of Wisconsin-Whitewater Recipient: Igor Shoikhedbrod, University of Toronto

Title: "Rights Discourse and Economic Domination: Thinking Beyond the Narrow Horizon of Liberal Justice." PhD diss., University of Toronto

\section{SECTION 28. POLITICAL PSYCHOLOGY}

\section{Political Psychology Career Achievement Award}

The Political Psychology Career Achievement Award is awarded biennially to recognize a scholar whose lifetime scholarship and service to the profession has made an outstanding contribution to the field of political psychology.

Award Committee: Howard Lavine, University of Minnesota; Deborah Schildkraut, Tufts University; Loren Collingwood, University of California, Riverside Recipient: Donald R. Kinder, University of Michigan

\section{Robert E. Lane Best Book Award}

The Robert E. Lane Award for the best book in political psychology published in the past year.

Award Committee: Samara Klar, Chair, University of Arizona; Yanna Krupnikov, The State University of New York at Stony Brook; Virginia Sapiro, Boston University

Recipient: Gwyneth McClendon, New York University

Title: Envy in Politics. Princeton University Press, 2018.

\section{Best Paper Award}

The Best Paper Award is given to the most outstanding paper in political psychology delivered at the previous year's annual meeting.

Award Committee: Jennifer Wolak, University of Colorado Boulder; Michael Sances, University of Memphis; Bert Bakker, Amsterdam School of Communication Research

Recipients: Vin Arceneaux, Temple University; Michael Bang Petersen, Aarhus University; Mathias Osmundsen, Aarhus University

Title: "A 'Need for Chaos' and the Sharing of Hostile Political Rumors in Advanced Democracies." Unpublished manuscript, presented at the APSA Annual Meeting, 2018.

\section{Best Dissertation Award}

The Best Dissertation Award is given for the best dissertation in political psychology filed during the previous year.

Award Committee: Rick Lau, Chair, Rutgers University; Kris-Stella Trump, Social Science Research Council; Adam Thal, Yale University

Recipient: Pavielle Haines, University of Denver

Title: "A Vote for Me Is a Vote for America: Patriotic Appeals in Presidential Elections." PhD diss., Princeton University.

\section{Distinguished Junior Scholars Award}

The APSA Political Psychology section gives Distinguished Junior Scholar Awards as grants to junior scholars (graduate students or those no more than seven years since receiving their Ph.D) to help fund their travel to the APSA meeting.

Award Committee: Jane Junn, University of Southern California; Alex Coppock, Yale University; Ali Valenzuela, Princeton University; Christopher Johnston, Duke University

Recipients: Tyler Reny, University of California, Los Angeles; Joshua Kertzer, Harvard University

\section{SECTION 29. POLITICAL SCIENCE EDUCATION}

Craig L. Brians Award for Excellence in Undergraduate Research and Mentorship Established in 2014, this award will be awarded annually at the Teaching and Learning Conference, with recognition also given at the APSA annual PSE section reception.

Award Committee: Carlos Huerta, Texas A\&M University, Corpus Christi; Fletcher McClellan, Elizabethtown College; Allison McCartney, Towson University Recipient: Celeste Montoya, University of Colorado Boulder

The Best APSA Conference Paper Award The Best Paper Presentation Award is given for the best presentation on undergraduate education at the past year's APSA Annual Meeting.

Award Committee: Michael Rogers, Arkansas Tech University; Bobbi Gentry, Bridgewater College; Terry Gilmour, Midland College Recipient: Diana Owen, Georgetown University 
Title: "Teaching Civics to High-Need Students." Unpublished manuscript, presented at the APSA Annual Meeting, 2018.

\section{The Distinguished Service Award}

This award is presented to a person who has a strong record of exceptional and extensive contributions to the goals of the section, including the promotion of teaching and learning in the discipline and the scholarship of teaching.

Award Committee: Sherri Wallace, University of Louisville; Elizabeth Bennion, Indiana University, South Bend; Boris Ricks, California State University, Northridge; Thomas Ringenberg, Rockhurst University; Michael Rogers, Arkansas Tech University; Bobbi Gentry, Bridgewater College; Donald Gooch, Stephen F. Austin University; Joseph Roberts, Roger Williams University; Terry Gilmour, Midland College; Patrick McKinlay, Morningside College

Recipient: Victor Asal, State University of New York at Albany

\section{Lifetime Achievement Award}

The Lifetime Achievement Award is given to a person whose lifetime contribution to political science have had a significant impact on undergraduate education.

Award Committee: Sherri Wallace, University of Louisville; Elizabeth Bennion, Indiana University, South Bend; Boris Ricks, California State University, Northridge; Thomas Ringenberg, Rockhurst University; Michael Rogers, Arkansas Tech University; Bobbi Gentry, Bridgewater College; Donald Gooch, Stephen F. Austin University; Joseph Roberts, Roger Williams University; Terry Gilmour, Midland College; Patrick McKinlay, Morningside College Recipient: Michael Brintnall

\section{SECTION 31. FOREIGN POLICY}

\section{Best Paper Award}

The best paper on foreign policy presented at the previous year's APSA Annual Meeting.

Award Committee: Thomas M. Dolan, University of Central Florida; Jennifer Raymond Dresden, Georgetown University; Megan Stewart, American University Recipient: Shannon Carcelli, University of Maryland

Title: "Bureaucracy at the Border." Unpublished manuscript, presented at the APSA Annual Meeting, 2018.

Honorable Mention: Chad Nelson, Brigham Young University
Title: "Revolutionary Contagion and the Islamic Revolution in the Middle East." Unpublished manuscript, presented at the APSA Annual Meeting, 2018.

\section{Best Graduate Student Paper Award}

Panel chairs from any division are invited to nominate outstanding graduate student papers presented at the APSA Annual Meeting that are relevant to the study of foreign policy.

Award Committee: Thomas M. Dolan, University of Central Florida; Jennifer Raymond Dresden, Georgetown University; Megan Stewart, American University

Recipient: Maryum Alam, University of Indiana

Title: "State Sponsorship as a Two-Level Game." Unpublished manuscript, presented at the APSA Annual Meeting, 2018.

\section{Best Book Award}

The best book on foreign policy published in 2017 or 2018.

Award Committee: Thomas M. Dolan, University of Central Florida; Jennifer Raymond Dresden, Georgetown University; Rebecca Davis Gibbons, Belfer Center

Recipient: Keren Yarhi-Milo, Princeton University

Title: Who Fights for Reputation. Princeton University Press, 2018.

Recipient: Eric Grynaviski, George Washington University

Title: America's Middlemen. Cambridge University Press, 2018.

\section{SECTION 32. ELECTIONS, PUBLIC} OPINION, AND VOTING BEHAVIOR

\section{Philip E. Converse Best Book Award}

The Philip E. Converse Book Award is given for an outstanding book in the field published at least five years before.

Award Committee: Caroline Tolbert, Chair, University of Iowa; Laura Stoker, University of California, Berkeley; Ed Fieldhouse, University of Manchester

Recipients: Donald P. Green, Columbia University; Bradley Palmquest; Eric Schickler, University of California, Berkeley

Title: Partisan Hearts and Minds: Political Parties and the Social Identities of Voters. Yale University Press, 2002.

\section{Emerging Scholar Award}

The Emerging Scholar Award is awarded to the top scholar in the field who is within 10 years of her or his $\mathrm{PhD}$.
Award Committee: Samara Klar, Chair, University of Arizona; Stephen Mockabee, University of Cincinnati; Rebecca WeitzShapiro, Brown University

Recipient: Anand Sokhey, University of Colorado Boulder

\section{Best Paper Award}

The Best Paper Award is given for the best paper delivered at the previous year's APSA Annual Meeting.

Award Committee: Jim Garand, Chair, Louisiana State University; Karen Jusko, Stanford University; Tyson King-Meadows, University of Maryland, Baltimore County Recipients: Maggie A. Deichert, Vanderbilt University; Stephen N. Goggin, San Diego State University; Alexander Theodoridis, University of California, Merced

Title: "God, Sex, and Especially Politics: Disentangling the Dimensions of Discrimination." Unpublished manuscript, presented at the APSA Annual Meeting 2018.

Recipients: Sara B. Holbolt, London School of Economics; Thomas J. Leeper, London School of Economics; James Tilley, Oxford University

Title: "Divided by the Vote: Affective Polarization in the Wake of Brexit." Unpublished manuscript, presented at the APSA Annual Meeting 2018.

Best Article in Political Behavior Award This award is for the best article published in Political Behavior in the previous calendar year.

Award Committee: David Kimball, Chair, University of Missouri-St. Louis; Sunshine Hillygus, Duke University; Lilliana Mason, University of Maryland

Recipient: Cecilia H. Mo, University of California, Berkeley

Title: "Perceived Relative Deprivation and Risk: An Aspiration-Based Model of Human Trafficking Vulnerability." Political Behavior 40 (1): 247-77.

\section{John Sullivan Award}

The John Sullivan Award for the best paper by a graduate student on a panel sponsored by the APSA Organized Section on Elections, Public Opinion, and Voting Behavior at the previous APSA Annual Meeting.

Award Committee: Cindy Kam, Chair, Vanderbilt University; Christina Farhart, Carleton College; Israel Waismel-Manor, University of Haifa

Recipient: Bradley Spahn, Stanford University 
Title: "Before Stable Partisanship." Unpublished manuscript, presented at the APSA Annual Meeting, 2018.

\section{Graduate Student Travel Awards}

Multiple grants awarded to graduate students who are authors or co-authors of papers on a panel or poster session sponsored by the section at the 2018 annual meeting.

Award Committee: Adam Brown, Chair, Brigham Young University; David Lublin, American University; LaFleur Stephens, Princeton University

Recipients: Elizabeth Schmitt, University of Arizona; Caitlin Davies, The State University of New York at Stony Brook; Brian Hamel, University of California, Los Angeles; Aykut Ozturk, Syracuse University

\section{SECTION 33. RACE, ETHNICITY, AND POLITICS}

\section{Best Book in Race, Ethnicity, and Politi-} cal Behavior Award

The Best Book Award is given for the best book in the field of Race, Ethnicity, and Politics.

Award Committee: Shatema Threadcraft, Dartmouth College; Spencer Piston, Boston University; Sophia Wallace, University of Washington

Recipient: Bernard Fraga, Indiana University

Title: The Turnout Gap: Race, Ethnicity, and Political Equality in a Diversifying America. Cambridge University Press, 2018.

Best Book in Race, Ethnicity, and Political Development Award

The Best Book Award is given for the best book in the field of Race, Ethnicity, and Politics.

Award Committee: Shatema Threadcraft, Dartmouth College; Spencer Piston, Boston University; Sophia Wallace, University of Washington

Recipient: Thomas Ogorzalek, Northwestern University

Title: The Cities on the Hill: How Urban Institutions Transformed National Politics. Oxford University Press, 2018.

\section{Best Book in Race, Ethnicity, and Urban Politics Award}

The Best Book Award is given for the best book in the field of Race, Ethnicity, and Politics.

Award Committee: Shatema Threadcraft, Dartmouth College; Spencer Piston, Boston
University; Sophia Wallace, University of Washington

Recipient: Jessica Trounstine, University of California, Merced

Title: Segregation by Design: Local Politics and Inequality in American Cities. Cambridge University Press, 2018.

Best Book in Race, Ethnicity, and Comparative Politics Award

The Best Book Award is given for the best book in the field of Race, Ethnicity, and Politics.

Award Committee: Shatema Threadcraft, Dartmouth College; Spencer Piston, Boston University; Sophia Wallace, University of Washington

Recipient: Penelope Anthias, University of Copenhagen

Title: Limits to Decolonization: Indigeneity, Territory, and Hydrocarbon Politics in Bolivian Chaco. Cornell University Press, 2018.

\section{Best Dissertation Award}

The Best Dissertation Award is given for the best American dissertation on Race, Ethnicity, and Politics accepted in the previous year. Award Committee: LaFleur Stephens, Princeton University; Valeria Sinclair-Chapman, Purdue University; Ismail White, Duke University

Recipient: Angela Ocampo, University of Michigan

Title: "The Politics of Inclusion: A Sense of Belonging to US Society and Latino Political Participation." PhD diss., University of California, Los Angeles.

Recipient: Julian Wamble, The State University of New York at Stony Brook

Title: "Show Us That You Care: How Community Commitment Signals Affect Black Political Considerations." PhD diss., University of Maryland.

\section{Best Paper Award}

The Best Paper Award is given for the best paper on Race, Ethnicity, and Politics presented at the previous year's APSA Annual Meeting.

Award Committee: Allison Anoll, Vanderbilt University; Sergio Garcia-Rios, Cornell University; Danielle Lemi, Southern Methodist University

Recipient: Hannah Walker, Rutgers University, New Brunswick; Kassra Oskooii, University of Delaware; Nazita Lajevardi, Michigan State University; Aubrey Westfall, Wheaton College

Title: "The Paradox Between Integration and Perceived Discrimination Among U.S.
Muslims." Unpublished manuscript, presented at the APSA Annual Meeting, 2018. Recipient: Diane Wong, Cornell University Title: "When Women Hold Up the Sky: Shop Talk and Everyday Resistance to Gentrification in Manhattan's Chinatown." Unpublished manuscript, presented at the APSA Annual Meeting, 2018.

SECTION 34. INTERNATIONAL HISTORY AND POLITICS

\section{Robert L. Jervis and Paul W. Schroeder Best Book Award}

The Robert L. Jervis and Paul Schroeder Best Book Award for the best book on International History and Politics.

Award Committee: Catherine Lu, McGill University; Mlada Bukovansky, Smith College; John Duffield, Georgia State University

Recipient: Arjun Chowdhury, University of British Columbia

Title: The Myth of International Order: Why Weak States Persist and Alternatives to the State Fade Away. Oxford University Press, 2018.

\section{Outstanding Article Award in Interna-} tional History and Politics

The Outstanding Article Award in International History and Politics recognizes exceptional peer-reviewed journal articles representing the mission of the International History and Politics Section of the

APSA, including innovative work that brings new light to events and processes in international politics, encourages interdisciplinary conversations between political scientists and historians, and advances historiographical methods.

Award Committee: Ido Oren, Chair, University of Florida; Cheryl Shanks, Williams College; Brendan Green, University of Cincinnati

Recipient: Christopher Darnton, Naval Postgraduate School

Title: "Archives and Inference: Documentary Evidence in Case Study Research and the Debate over US Entry into World War II." International Security 42 (3): 84-126.

\section{SECTION 35. COMPARATIVE} DEMOCRATIZATION

\section{Juan Linz Best Dissertation Award}

Given for the best dissertation in the Comparative Study of Democracy completed and accepted in the two calendar years 
immediately prior to the APSA Annual Meeting.

Award Committee: Soleded Prillaman, Chair, University of Oxford; Elizabeth R. Nugent, Yale University; Noam Lupu, Vanderbilt University

Recipient: Nikhar Gaikwad, Yale University Title: "Identity Politics and Economic Policy.” PhD diss., Columbia University.

\section{Best Book Award}

Given for the best book in the field of Comparative Democratization published in 2018 (authored, co-authored or edited).

Award Committee: Jan Teorell, Chair, Lund University; Maya Tudor, Stanford University; Seva Gunitsky, University of Toronto Recipient: Deborah Yashar, Princeton University

Title: Homicidal Ecologies: Illicit Economies and Complicit States in Latin America, Cambridge University Press, 2018.

\section{Best Article Award}

Single-authored or co-authored articles focusing directly on the subject of democratization and published in 2018 are eligible. Award Committee: Michael Albertus, Chair, University of Chicago; Bryn Rosenfeld, University of Southern California; Jason Wittenberg, University of California, Berkeley

Recipient: Fiona Shen-Bayh, University of California, Berkeley

Title: "Strategies of Repression." World Politics 70 (3): 321-357.

Recipient: Aditya Dasgupta, University of California, Merced

Title: "Technological Change and Political Turnover." American Political Science Review, 112 (4): 918-938.

\section{Best Field Work Award}

This prize rewards dissertation students who conduct especially innovative and difficult fieldwork. Scholars who are currently writing their dissertations or who complete their dissertations in 2018 are eligible.

Award Committee: Egor Lazarev, Chair, University of Toronto; Sule Yaylaci, University of British Columbia; H. Zeynep Bulutgil, University of College London

Recipients: Rachael S. McLellan, Princeton University; Hind Ahmed Zaki, University of Washington

\section{Best Paper Award}

Given to the best paper on Comparative Democratization presented at the previous year's APSA Annual Meeting. Papers must be nominated by panel chairs or discussants.

Award Committee: Daniel Treisman, Chair, University of California, Los Angeles; Imke Harbers, University of Amsterdam; Agustina Giraudy, American University Recipient: Mariano Sánchez-Talanquer, Centro de Investigación y Docencia Económicas (CIDE)

Title: "Suffrage Restrictions and the Reach of the Nation-State." Unpublished manuscript, presented at the APSA Annual Meeting, 2018.

\section{SECTION 36. HUMAN RIGHTS}

\section{Best Book Award}

The Best Book Award recognizes the best book on human rights written by a political scientist and published in the previous two years.

Award Committee: George Andreopolous, Chair, The City University of New York John Jay College of Criminal Justice; Bethany Barratt, Roosevelt University; Alison Dundes Renteln, University of Southern California

Recipient: Margaret Roberts, University of California, San Diego

Title: Censored: Distraction and Diversion Inside China's Great Firewall. Princeton University Press, 2018.

Honorable Mention: Daniel C. Lewis, Siena College; Donald P. Haider-Markel, University of Kansas; Jami K. Taylor, University of Toledo

Title: The Remarkable Rise of Transgender Rights. University of Michigan Press, 2018.

\section{Best Dissertation Award}

The Best Dissertation Award recognizes the best dissertation in the field of human rights.

Award Committee: Alison Brysk, Chair, University of California, Santa Barbara; Marijke Breuning, University of North Texas; Lucas Swaine, Dartmouth College

Recipient: Andrew Vilan, University of California, Los Angeles

Title: "Domestic Compliance with International Human Rights Norms." PhD diss., University of California, Los Angeles.

\section{Best Paper Award}

The Best Paper Award recognizes the best paper presented on a Human Rights Section Panel at the APSA Annual Meeting. Award Committee: Brian Greenhill, Chair, The State University of New York at Albany;
Shareen Hertel, University of Connecticut; Karen Zivi, Grand Valley State University Recipients: Kelebogile Zvobgo, University of Southern California; Wayne Sandholz, University of Southern California Title: "Reserving Rights: Examining Human Rights Treaty Reservations." Unpublished manuscript, presented at the APSA Annual Meeting, 2018.

\section{SECTION 37. QUALITATIVE AND} MULTI-METHOD RESEARCH

\section{Giovanni Sartori Book Award}

The Giovanni Sartori Book Award honors Giovanni Sartori's work on qualitative methods and concept formation, and especially his contribution to helping scholars think about problems of context as they refine concepts and apply them to new spatial and temporal settings. The award is intended to encompass two types of contributions: new research on methodology per se, i.e., studies that introduce specific methodological innovations or that synthesize and integrate methodological ideas in a way that is in itself a methodological contribution; and substantive work that is an exemplar for the application of qualitative methods.

Award Committee: Alisha Holland, Princeton University; Nuno Monteiro, Yale University; Andrew Bennett, Georgetown University

Recipient: Simeon Nichter, University of California, San Diego

Title: Votes for Survival: Relational Clientelism in Latin America. Cambridge University Press, 2018.

Honorable Mention:Abigail Fisher Williamson, Trinity College

Title: Welcoming New Americans: Local Governments and Immigrant Incorporation. University of Chicago Press, 2018.

\section{Alexander L. George Article-Chapter Award}

The Alexander L. George Article Award honors Alexander George's contributions to the comparative case-study method, including his work linking that method to a systematic concern with research design, and his contribution of developing the idea and the practice of process tracing. This award may be granted to a journal article or to a chapter in an edited volume that stands on its own as an article. The award will be given to an article or book chapter published in the calendar year prior to the year of the APSA meeting at which the award 
is presented, with the date of publication being established by the journal issue for articles and the copyright date of the book for chapters.

Award Committee: Lindsay Mayka, Chair, Colby College; Jack Levy, Rutgers University; Katherine Baldwin, Yale University Recipients: Jennifer Larson, Vanderbilt University; Janet Lewis, United States Naval Academy

Title: "Rumors, Kinship Networks, and Rebel Group Formation." International Organization 72 (4): 871-903.

Honorable Mentions: Paul Musgrave, University of Massachusetts at Amherst; Daniel Nexon, Georgetown University

Title: "Defending Hierarchy from the Moon to the Indian Ocean: Symbolic Capital and Political Dominance in Early Modern China and the Cold War." International Organization 72 (3): 591-626.

\section{Sage Paper Award}

The Sage Paper Award honors Sara and George McCune, who founded and sustained Sage Publications as a leading publisher of social science methodologyincluding very centrally qualitative methods. This award will be given to a paper presented at the previous Annual Meeting of the American Political Science Association. Award Committee: Matthew Amengual, Oxford University; Sara Newland, Smith College; Elliot Posner, Case Western Reserve University

Recipients: Paul Schuler, University of Arizona; Chad Westerland, University of Arizona

Title: "Reconsidering the Rubber Stamp Thesis: A Consolidation Theory of Expropriations and Legislatures in Party-based Autocracies." Unpublished manuscript, presented at the APSA Annual Meeting, 2018.

\section{David Collier Mid-Career Achievement Award}

The award honors David Collier's contributions-through his research, graduate teaching, and institution-building-as a founder of the qualitative and multi-method research movement in contemporary political science. The award will be presented annually to a mid-career political scientist to recognize distinction in methodological publications, innovative application of qualitative and multi-method approaches in substantive research, and/or institutional contributions to this area of methodology.
Award Committee: Melani Cammett, Harvard University; Jason Seawright, Northwestern University; Markus Kreuzer, Villanova University

Recipient: Carsten Schneider, Central European University

\section{SECTION 38. SEXUALITY AND POLITICS}

\section{Cynthia Weber Best Conference Paper} Award

The Best Conference Paper Award recognizes the best paper exploring sexuality and politics presented at the previous year's APSA Annual Meeting.

Award Committee: Iñaki Sagarzazu, Chair, Texas Tech University; Zein Murib, Fordham University; Anna Weissman, University of Florida

Recipient: H. Howell Williams, Western Connecticut State University

Title: "From Family Values to Religious Freedom: Tracing Conservative Opposition to Gay Rights." Unpublished manuscript, presented at the 2018 APSA Annual Meeting.

Kenneth Sherrill Best Dissertation Award The Best Dissertation Award recognizes the best dissertation on sexuality and politics completed and successfully defended in the previous two calendar years.

Award Committee: Megan Osterbur, Chair, New England College; Edward Kammerer, Skidmore College; Ravi Perry, Howard University

Recipient: Joanna Wuest, University of Pennsylvania

Title: "Born this Way: Scientific Authority and Citizenship in the American LGBTQ Movement." PhD diss., University of Pennsylvania.

\section{SECTION 39. HEALTH POLITICS AND} POLICY

\section{Leonard S. Robins Best Paper Award}

The Len Robins Best Paper on Health Politics and Policy Award, honors the late Len Robins, who through his presence and gentle questioning at virtually every health politics panel graciously nurtured the scholarship of both junior and senior scholars.

Award Committee: Elizabeth Rigby, Chair, The George Washington University; Matthew Kavanagh, Georgetown University; Isabel Perera, University of Pennsylvania Recipients: Steven Sylvester, Utah Valley
University; Simon Haeder, West Virginia University; Timothy Callaghan, Texas A\&M University

Title: "Just Say No? Attribution Theory and Public Attitudes About the Opioid Epidemic." Unpublished manuscript.

\section{Outstanding Public Engagement in Health Policy Award}

Awarded to an individual who has been working to improve health and the health care system by actively engaging in politics and policy making.

Award Committee: Julia Lynch, University of Pennsylvania; Miriam Laugesen, Columbia University; Jacqueline Chattopadhyay, University of North Carolina, Charlotte; John Hoornbeek, Kent State University; Scott Greer, University of Michigan; David Jones, Boston University; Jamila Michener, Cornell University; Philip Rocco, Marquette University

Recipient: Sara Rosenbaum, The George Washington University

\section{SECTION 40. CANADIAN POLITICS}

Mildred Schwartz Lifetime Achievement The Mildred A. Schwartz Lifetime Achievement Award recognizes scholarship and leadership in bringing the study of Canadian Politics to the international political science community.

Award Committee: Antoine Yoshinaka, Chair, The State University of New York at Buffalo; Candace Johnson, University of Guelph; Ross Burkhart, Boise State University; Cristine de Clercy, University of Western Ontario

Recipient: Grace Skogstad, University of Toronto

Seymour Martin Lipset Best Book Award The Seymour Martin Lipset Best Book Award is given to honor a significant contemporary contribution to the scholarship on Canadian politics, or Canada in a comparative perspective, or a comparative analysis of Canada with other countries, particularly the United States.

Award Committee: Cristine de Clercy, University of Western Ontario; Debra Thompson, University of Oregon; Ross Burkhart, Boise State University

Recipient: Richard Johnston, University of British Columbia

Title: The Canadian Party System: An Analytic History. University of British Columbia Press, 2017.

Recipient:Paul Saurette, University of Ottawa 
Title: The Changing Voice of the Anti-Abortion Movement: The Rise of "Pro-Woman" Rhetoric in Canada and the United States. University of Toronto Press, 2015.

\section{SECTION 41. POLITICAL NETWORKS}

\section{Political Ties Award}

This award is given on a biennial basis to the best article published on political networks.

Award Committee: Isabella Alcaniz, University of Maryland; Matthew Pietryka, Florida State University; Javier Sajuria, Queen Mary University of London

Recipient: Marina Duque, Florida State University

Title: "Recognizing International Status: A Relational Approach." International Studies Quarterly 62(3): 577-592.

\section{Best Conference Paper Award}

This award is given annually to the best paper on political networks presented by a faculty person delivered at a political science conference in the previous year.

Award Committee: Zachary SteinertThrelkeld, University of California, Los Angeles; Amanda Friesen, Indiana University-Purdue University Indianapolis; Matthew Denny, Facebook

Recipient:Taylor Carlson, University of California San Diego

Title: "Through the Grapevine: Informational Consequences of Interpersonal Political Communication." American Political Science Review 113 (2): 325-339.

\section{John Sprague Award}

This award is given annually to the best paper on political networks presented by a graduate student delivered at a political science conference in the previous year. There is a fund that supports this award and the award includes a cash award that comes from the fund.

Award Committee: Olga Chyzh, Iowa State University; Marina Duque, Florida State University;Josh McCrain, Emory University Recipient: Taylor Carlson, University ofCalifornia San Diego

Title: "Through the Grapevine: Informational Consequences of Interpersonal Political Communication." American Political Science Review 113 (2): 325-339.

\section{Best Book Award}

The best book award is given on a biennial basis to the best book published on political networks.
Award Committee: Laila Wahedi, Georgetown University; Ramiro Berardo, Ohio State University; Jennifer Hadden, University of Maryland

Recipient: Michael Kenney, University of Pittsburgh

Title: The Islamic State in Britain. Cambrige University Press, 2018.

Honorable Mention: Jaime Settle, The College of William \& Mary

Title: Frenemies. Cambridge University Press, 2018.

\section{Best Poster Award}

This award is given annually at the Political Networks Conference and is awarded to the one (or two) best posters on political networks. Typically, two awards are given, but this is not a requirement.

Award Committee: Zhengqi Pan, Singapore University of Social Sciences; Yotam Shmargad, University of Arizona; Nick Beauchamp, Northeastern University; Christine Bricker, Warren Wilson College; Kevin Young, University of Massachusetts at Amherst

Recipients: Sahar Abi-Hassan, Boston University; Janet M. Box-Steffensmeier, Ohio State University; Dino P. Christenson, Boston University; Aaron Russell Kaufman, Harvard University; Brian Libgober, Yale University

Title: "Large-Scale Estimation of Interest Group Ideal Points." Presented at the 2019 Political Networks Conference.

Recipient: Bi Zhao, Purdue University Title: "Better Together?: A Network Analysis of NGOs at UN Climate Change Governance." Presented at the 2019 Political Networks Conference.

\section{SECTION 42. EXPERIMENTAL RESEARCH}

\section{Best Experimental Research Paper Award}

The Best Paper Award recognizes a paper that was scheduled to be presented at APSA in 2018 and features experimental research.

Award Committee: Peter Loewen, University of Toronto; Sera Linardi, University of Pittsburgh

Recipients: Pia Raffler, Harvard University; Daniel Posner, University of California, Los Angeles; Doug Parkerson, Innovations for Poverty Action

Title: "The Weakness of Bottom-UpAccountability: Experimental Evidence from the Ugandan Health Sector." Unpublished manuscript, presented at the APSA Annual Meeting, 2018.

Best Experimental Research Book Award The Best Book Award recognizes the best book published in 2018 that either uses or is about experimental research methods in the study of politics.

Award Committee: Cyrus Samii, New York University; Nichole Bauer, Louisiana State University; Victoria Shineman, University of Pittsburgh

Recipient: Jaime Settle, The College of William \& Mary

Title: Frenemies: How Social Media Polarizes America. Cambridge University Press, 2018. Honorable Mentions: Michael Neblo, Ohio State University; Kevin Esterling, University of California, Riverside; David Lazer, Northeastern University

Title: Politics with the People: Building a Directly Representative Democracy. Cambridge University Press, 2018.

\section{Best Experimental Research Dissertation Award}

The Best Dissertation Award recognizes the best dissertation completed in calendar year 2018 that utilizes experimental methods on substantive questions about politics or makes a fundamental contribution to experimental methods.

Award Committee: Peter DeScioli, The State University of New York at Stony Brook; Jennifer Larson, Vanderbilt University; Peter van der Windt, New York University Abu Dhabi

Recipient: Adam Zelizer, Columbia University

Title: "Legislating while learning: How staff briefings, cue-taking, and deliberation help legislators take policy positions." $\mathrm{PhD}$ diss., Columbia University.

\section{Experimental Research Public Service Award}

Many experiments only occur thanks to the assistance of non-researchers who provide access to resources and data. This award recognizes a special form of public service, the facilitation of randomized experiments in political science by those outside the academy.

Award Committee: Kelly Bidwell, US Government; Christopher Mann, Skidmore College; Reuben Kline, The State University of New York at Stony Brook

Recipient: Rebecca Wolfe, Mercy Corps Honorable Mention: Anjali Chainani, City of Philadelphia 
SECTION 43. MIGRATION AND

CITIZENSHIP

\section{Best Paper Award}

Award for best paper on migration and/or citizenship presented at the previous APSA Annual Meeting (either as part of a panel or poster session).

Award Committee: Alex Street, Carroll College; Allan Colbern, Arizona State University; Floris Peters, Maastricht University

Recipient: Mathilde Emeriau, Stanford University

Title: "Learning to be Unbiased: Evidence from the French Asylum Office." Unpublished manuscript, 2018.

Honorable Mention: Alex Kustov, Princeton University

Title: "Borders of Compassion: International Migration and the Politics of Parochial Altruism." Unpublished manuscript, 2018.

\section{Best Dissertation Award}

Award for best dissertation on migration and/or citizenship accepted in the previous calendar year.

Award Committee: Jonathan Laurence, Boston College; Noora Lori, Boston University; Myra Waterbury, Ohio University

Recipient: Stephanie Schwartz, Columbia University

Title: "Homeward Bound: Return Migration and Local Conflict after Civil War." PhD diss., Columbia University.

\section{Best Article Award}

Award for best article on migration and/or citizenship accepted in the previous calendar year.

Award Committee: Margaret Peters, University of California, Los Angeles; Martin Heisler, University of Maryland, College Park; Dara Strolovitch, Princeton University

Recipient: Jeffrey D. Pugh, University of Massachusetts, Boston

Title: "Negotiating Identity and Belonging through the Invisibility Bargain: Colombian Forced Migrants in Ecuador." International Migration Review 52 (4): 978-1010.

\section{Best Book Award}

Best Book Award for the best book on migration and/or citizenship published in the previous year.

Award Committee: Robert Ford, University of Manchester; Oxana Shevel, Tufts University; Rebecca Hamlin, University of Massachusetts
Recipient: Elizabeth Cohen, Syracuse University

Title: The Political Value of Time. Cambridge University Press, 2018.

Honorable Mention:Abigail Fisher Williamson, Trinity College

Title: Welcoming New Americans? Local Governments and Immigrant Incorporation. University of Chicago Press, 2018.

Honorable Mentions: Anna Boucher, University of Sydney; Justin Gest, George Mason University

Title: Crossroads: Comparative Immigration Regimes in a World of Demographic Change. Cambridge University Press, 2018.

\section{SECTION 45. CLASS AND} INEQUALITY

\section{Kauffman Foundation Award for Best} Paper on Inclusion and Entrepreneurship The best paper written, presented, or published in the last year by a member of the APSA that is relevant to the to the context of entrepreneurs and their activities, their ecosystems and external environments, and related practitioners and policymakers. Award Committee: David Broockman, University of California, Berkeley; Christopher Witko, Pennsylvania State University Recipient: Alex Gourevitch, Brown University

Title: "Political Theory of the Entrepreneur." Unpublished manuscript.

Kauffman Foundation Award for Best Graduate Student Paper on Inclusion and Entrepreneurship

The best paper written, presented, or published in the last year by a graduate student member of the APSA that is relevant to the to the context of entrepreneurs and their activities, their ecosystems and external environments, and related practitioners and policymakers.

Award Committee: David Broockman, University of California, Berkeley; Christopher Witko, Pennsylvania State University Recipient: Adaugo Pamela Nwakanma, Harvard University

Title: "Women, Entrepreneurship and Economic Development in Africa." The Palgrave Handbook of African Women's Studies. Palgrave Macmillan, Cham, 2019.

\section{SECTION 46. IDEAS, KNOWLEDGE AND POLITICS}

Ideas, Knowledge and Politics Graduate Student Paper Award
The Ideas, Knowledge, and Politics (IKP) division announces its graduate student paper prize. This $\$ 500$ cash award will recognize the APSA conference paper by a graduate student, presented at an IKP panel at the 2018 annual meetings, that best explored the role of ideas or knowledge in politics or government.

Award Committee: Jeffrey Friedman, University of California, Berkeley; Paul Gunn, Goldsmith's, University of London

Recipient: Naomi Scheinerman, Yale University

Title: "Anti-Vaccination in the Trump Era: Mistrust of Experts and the Promise of Democracy." Unpublished manuscript, presented at the APSA Annual Meeting, 2018.

\section{Ideas, Knowledge, and Politics Best Book Award}

The Ideas, Knowledge, and Politics (IKP) Best Book Award is for the best recent work on empirical or normative aspects of the role of ideas or knowledge in politics or government.

Award Committee: Paul Gunn, Goldsmith's, University of London; Hélène Landemore, Yale University; Benjamin Miller, University of Illinois, Urbana-Champaign; Jacob Roundtree, Harvard University

Recipients: Robert E. Goodin, Australian National University; Kai Spiekermann, London School of Economics and Political Science

Title: An Epistemic Theory of Democracy. Oxford University Press, 2018.

\section{SECTION 47. AMERICAN POLITICAL THOUGHT}

\section{Best Book Award}

The Best Book in American Political Thought Award will be chosen every year by the section council.

Award Committee: Michael Zuckert, University of Notre Dame; Jeremy Bailey, University of Houston; Natalie Taylor, Skidmore College

Recipient: Jonathan Gienapp, Stanford University

Title: The Second Creation: Fixing the American Constitution in the Founding Era. Harvard University Press, 2018.

\section{Best Article Award}

The Best Article in American Political Thought will be chosen every year by the Section Council from among the articles published in the journal American Political Thought. 
Award Committee: George Thomas, Claremont McKenna College; James Stoner, Louisiana State University; Connor Ewing, University of Toronto

Recipient: Sean Beienburg, Arizona State University

Title: "Neither Nullification nor Nationalism: The Battle for the States' Rights Middle Ground during Prohibition." American Political Thought 7 (2): 271-303.

\section{Best Dissertation Award}

The Best Dissertation in American Political Thought Award is chosen every two years by the Section Council. The council selects award recipients from nominations provided by the department chairs (one per department).

Award Committee: Greg Weiner, Assumption College; Nicholas Buccola, Linfield College; Susan McWilliams Barndt, Pomona Colege

Recipient: Zachary German, Arizona State University

Title: "Spirit, Statesmanship, and the New Science of Politics: Montesquieu, The Federalists, and the Anti-Federalists." PhD diss., University of Notre Dame, 2017.

\section{SECTION 48. INTERNATIONAL COLLABORATION}

\section{Best Article Award}

The Best Article Award is given for the best article on international collaboration published in 2018.

Award Committee: Sarah Bauerle Danzman, Indiana University Bloomington; Marina E. Henke, Northwestern University; Lauren Prather, University of California, San Diego
Recipient:Julia Gray, University of Pennsylvania

Title: "Life, Death, or Zombie? The Vitality of International Organizations." International Studies Quarterly, 62 (1): $1-13$.

\section{Best Book Award}

The Best Book Award is given for the best book on international collaboration published in 2018.

Award Committee: Julia Gray, University of Pennsylvania; Michaël Aklin, University of Pittsburgh; Elena McLean, The State University of New York at Buffalo

Recipient: Tanisha Fazal, University of Minnesota

Title: Wars of Law. Cornell University Press, 2018

Honorable Mentions: Abraham L. Newman, Georgetown University; Elliot Posner, Case Western Reserve University

Title: Voluntary Disruptions: International Soft Law, Finance, and Power. Oxford University Press, 2018.

\section{Best Dissertation Award}

The Best Dissertation Award is given for the best dissertation on international collaboration for a Ph.D. awarded in 2018.

Award Committee: Susan Allen, University of Mississippi; Geoffrey Wallace, University of Washington; Jeffrey Kucik, University of Arizona

Recipient: Ranjit Lall, London School of Economics

Title: "Making International Organizations Work: The Politics of Institutional Performance." PhD diss., Harvard University.

\section{Distinguished Mentor Award}

The Distinguished Mentor Award is given for excellence in mentoring graduate students and junior faculty in the study of international collaboration.

Award Committee: Leslie Johns, University of California, Los Angeles; Krzysztof J. Pelc McGill University; Jana Von Stein, Australian National University

Recipient: Helen V. Milner, Princeton University

\section{SECTION 49. MIDDLE EAST AND NORTH AFRICA POLITICS}

\section{Best Paper Presented at the 2018 Annual Meeting}

Award Committee: Quinn Mecham, Brigham Young University; Dan Corstange, Columbia University; David Walder, University of Virginia; Lindsay Benstead, Portland State University

Recipient: Diana Greenwald, The City College of New York

Title: "Coercive and Fiscal Capacity Development in Palestine." Unpublished manuscript, presented at the APSA Annual Meeting, 2018.

\section{Best Dissertation}

Award Committee: Sean Yom, Temple University; Michaelle Browers, Wake Forest University; Yael Zeira, University of Mississippi; Lindsay Benstead, Portland State University

Recipient: José Ciro Martínez, Trinity College, University of Cambridge

Title: "The Politics of Bread: State Power, Food Subsidies and Neoliberalization in Hashemite Jordan." PhD diss., University of Cambridge. 